Canadian

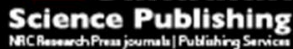

Canadian Geotechnical Journal Revue canadienne de géotechnique

\title{
Improvements to the Calculation of Actual Evaporation from Bare Soil Surfaces
}

\begin{tabular}{|r|l|}
\hline Journal: & Canadian Geotechnical Journal \\
\hline Manuscript ID: & cgj-2014-0512.R1 \\
\hline Manuscript Type: & Article \\
\hline Date Submitted by the Author: & $23-$ Apr-2015 \\
\hline Complete List of Authors: & $\begin{array}{l}\text { Tran, Dat; Thurber Engineering Ltd, } \\
\text { Fredlund, Delwyn; Golder Associates Ltd., Geotechnical Engineering } \\
\text { Chan, Dave; University of Alberta, }\end{array}$ \\
\hline Keyword: & $\begin{array}{l}\text { Soil suction, evaporation-rate reduction point, vapor pressure, relative } \\
\text { humidity, soil surface resistance }\end{array}$ \\
\hline
\end{tabular}




\title{
Improvements to the Calculation of Actual Evaporation from
}

\author{
Bare Soil Surfaces
}

\author{
${ }^{1}$ Dat T. Q. Tran, ${ }^{2}$ Delwyn G. Fredlund, ${ }^{3}$ Dave H. Chan
}

\section{ABSTRACT}

Evaporation of water from a saturated soil surface with ample free water is known as potential evaporation, $P E$, and the associated physical processes are quite well understood. However, evaporation of water from an unsaturated soil surface is known as actual evaporation, $A E$, and the associated physical processes are more complex and less understood. The calculation of actual evaporation is important for many geotechnical engineering applications. Soil suction and the corresponding water content at which the $A E$ rate begins to depart from the $P E$ rate during a drying process are re-assessed using a series of laboratory tests (i.e., thin soil section drying tests and soil column drying tests). Laboratory results show that the suction at which the actual rate of evaporation begins to depart from $P E$ rate for soil columns (or thick soil layers) may be different than for thin soil layers. The suction at the "evaporation-rate reduction point", (ERRP) appears to be approximately $3,000 \mathrm{kPa}$ for thin soil layers, but is between the air-entry value and residual soil suction for thick soil layers or soil columns. The analyses presented in this paper have resulted in the development of a methodology for the estimation of the suction corresponding to the ERRP in soil columns. Equations are also proposed to calculate the 
coefficient of surface moisture availability, the vapour pressure and "surface resistance" at ground surface. The paper also presents an equation (i.e., new soil-atmosphere moisture flux equation) for predicting the evaporation rate from a soil surface using "surface resistance" to vapour water diffusion from the soil to the atmosphere. The proposed soilatmosphere model is verified using evaporation rate data collected from various drying tests on thin soil layers and soil columns. Reasonably good agreement was found between the computed and measured rates of evaporation. The findings and recommendations in this paper contribute to an improved understanding of the prediction of $A E$ from unsaturated soil surfaces.

Keywords: Soil suction, evaporation-rate reduction point, vapour pressure, relative humidity, soil surface resistance, soil-atmosphere model.

1. Thurber Engineering Ltd., 180 - 7330 Fisher Street SE, Calgary, AB, Canada,T2H $2 \mathrm{H} 8$.

2. Golder Associates Ltd., 1721 - 8th Street East, Saskatoon, SK., Canada, S7H 0T4

3. University of Alberta, Geotechnical Engineering, Edmonton, AB, Canada, T6G 2W2.

Corresponding Author: Delwyn G. Fredlund

Telephone number: 306-261-8629

Email address: del_fredlund@golder.com mailto: 


\section{INTRODUCTION}

The evaporation of water from saturated and unsaturated soil surfaces is strongly influenced by net radiation from the sun and the movement of air above the ground surface. Wind has a mixing effect on the air near the ground surface. The mixing effect results in the removal of water vapour from near ground surface. At the same time that climatic forces are removing water the soil is holding onto and storing water in its pores (i.e., through soil suction or total suction). It can also be difficult to deliver water to the ground surface for evaporation because the coefficient of permeability of the unsaturated soil becomes extremely low. The net result of the competition between the weatherrelated factors and the suction in the soil is a reduction in the evaporation rate from $P E$, to $A E$.

Vapour pressure gradients constitute the principal driving mechanism for vapour flow. The difference in vapour pressure between the soil and the overlying air provides the vapour pressure gradient that drives $A E$. If the vapour pressure in the air above ground surface and the vapour pressure in the soil at ground surface are the same, then evaporation from the ground surface will cease since there is no longer a vapour pressure gradient (Fredlund et al., 2012).

Thermodynamic principles described in the form of Lord Kelvin's equation have been applied to the prediction of vapour pressure (or relative humidity) at the soil surface (Wilson et al., 1997). A prerequisite for applying Lord Kelvin's equation is that the air close to the pore-water surface must be in equilibrium with the pore-water. Such an equilibrium condition might not be maintained in a drying soil since the vapour pressure in the air 
adjacent to an evaporation front is not in equilibrium with the liquid water in the soil pores (Alvenas and Jansson, 1997). This non-equilibrium vapour pressure condition leads to the over-estimation of soil evaporation (Mihalovic et al., 1993; Alvenas and Jansson, 1997; Fredlund et al., 2011; and Dunmola, 2012).

In an effort to overcome deficiencies associated with directly applying Lord Kelvin's equation to soil surfaces, researchers have proposed methods to adjust or correct either the total suction or the relative humidity at the ground surface. Consequently, this has led to the introduction of a "total suction adjustment" factor or an empirical "relative humidity (or vapour pressure) adjustment" factor. For example, Kondo et al., (1990) empirically found the relative humidity at the soil surface began to decline at an average volumetric water content of $39.2 \%$ for sand and $49.0 \%$ for loam. Lee and Pielke (1992) suggested the relative humidity at the soil surface begins to drop once the soil volumetric water content is below field capacity. Van de Griend and Owe (1994) suggested that a volumetric water content of $15 \%$ could be used as the reference point when evaporation reduces for fine sand. These suggested values are empirical and are not parameters commonly used in geotechnical engineering.

The objective of the present study is to determine the suction at which $A E$, in soil columns and thin soil layers starts to reduce from PE. "Suction" or "soil suction" has two components; namely, matric suction and osmotic suction, the sum of which is total suction (Krahn and Fredlund, 1972). Common convention is to plot the water content versus matric suction for suctions up to $1500 \mathrm{kPa}$ along the $\mathrm{x}$-axis of the soil-water characteristic curve, SWCC. The water contents corresponding to total suctions greater than $1500 \mathrm{kPa}$ 
up to approximately $1,000,000 \mathrm{kPa}$ are then plotted for the remainder of the drying SWCC. The "suction" values are plotted on a logarithmic scale.

Of particular interest to this study is the rate of evaporation from coarse-grained sands in arid climatic conditions. A new theoretically-based soil-atmosphere moisture flux equation is proposed in this paper. The prediction of the evaporation rate from a soil surface utilizes the concept of "surface resistance" to vapour water diffusion from the soil surface to the atmosphere. Equations for the calculation of vapour pressure and soil "surface resistance" are proposed for the calculation of $A E$.

\section{BACKGROUND}

A brief review is presented on methods for estimating evaporation based on vapour pressure (or relative humidity) and soil "surface resistance" at the soil surface. Several models have been proposed to predict relative humidity at the surface of a soil. These methods can be divided into two categories. In the first category, total suction is adjusted based on the drying SWCC, and the thermodynamic relationship between the liquid and water vapour phases (Wilson, 1990; Alvenas and Jansson, 1997; Bittelli et al., 2008; Fredlund et al., 2011; and Dunmola, 2012). In the second category, relative humidity (or vapour pressure) is empirically determined based on parameterization of the surface specific humidity (Kondo et al., 1990; Mahfouf and Noilhan, 1991; and Lee and Pielke, 1992).

The thermodynamic relationship between soil suction and the partial pressure of porewater vapour (i.e., Lord Kelvin's equation), can be written as follows: 
$p_{v}=p_{v s a t} \times \exp \left(\frac{-\psi \omega_{v}}{R T \rho_{w}}\right)$

where: $\psi=$ total suction, $\mathrm{kPa} ; R=$ universal gas constant, $8.314 \mathrm{~J} / \mathrm{mol} . \mathrm{K} ; T=$ absolute temperature, $T=273.15+t^{\circ},{ }^{\circ} \mathrm{K} ; t^{o}=$ temperature, ${ }^{\circ} \mathrm{C} ; \rho_{w}=$ density of water, $\mathrm{kg} / \mathrm{m}^{3} ; \omega_{v}=$ molecular mass of water vapour, $18.016 \mathrm{~kg} / \mathrm{kmol} ; p_{v}=$ partial pressure of pore-water vapour, $\mathrm{kPa} ; p_{v s a t}=$ saturation pressure of pore-water vapour over a flat surface of pure water at the same temperature, $\mathrm{kPa}$.

Equation [1] is known as Lord Kelvin's equation and is equivalent to the thermodynamic equilibrium equation proposed by Philip (1957). Recently, Alvenas and Jansson (1997), Fredlund et al., (2011) and Dunmola (2012) attempted to apply the Lord Kelvin's equation for the calculation of $A E$ but suggested an adjustment to the total suction at the soil surface. Empirical correction factors were introduced to compensate for the difference between total suction at the evaporation front and the total suction at the ground surface.

Kondo et al., (1990), Mahfouf and Noilhan (1991) and Lee and Pielke (1992), on the other hand, proposed an equation that adjusted the vapour pressure (or relative humidity) at the soil surface. This equation introduced the concept of "surface resistance" to the transport of water vapour from the soil pores (i.e., the evaporation front) to the soil-atmosphere interface.

The term, "surface resistance" has been applied to account for the observed reduction in actual evaporation as a soil dries and becomes unsaturated. The "surface resistance" 
concept originated from the resistance of a canopy of vegetation to evaporation (Monteith, 1965). Later the concept of soil "surface resistance" was used to derive an equation to more accurately calculate actual evaporation from bare soil surfaces (Fen Shu, 1982; Camillo and Gurney, 1986; van de Griend and Owe, 1994; Aluwihare and Watanabe, 2003; Bittelli et al., 2008).

"Surface resistance" results from vapour diffusion across the water-air evaporation front internal to the soil pores, and the vapour flow through dry soil pores to the ground surface. The units for "surface resistance" are the inverse of those for vapour conductivity (i.e., units of s/m or seconds per meter) (van de Griend and Owe, 1994). The concept of "surface resistance" has become a useful means of representing resistance to evaporation near ground surface where the soil is unsaturated.

Equations estimating "surface resistance" introduced by Fen Shu (1982), Camillo and Gurney (1986), and van de Griend and Owe (1994) are summarized in Table 1. From a theoretical and practical standpoint, soil "surface resistance" varies from zero at a wet soil surface to a large value at a dry unsaturated soil surface (van de Griend and Owe, 1994).

\section{MATERIALS FOR TESTING}

Two soils of different textures were used in the testing program; namely, Ottawa sand and Devon silt. The Ottawa sand was washed silica sand with an average grain size of 0.42 mm, (purchased from Fisher Scientific). Devon silt was naturally-occurring silt composed of quartz, feldspar, and clay minerals. The grain-size distribution of Devon silt was measured at the Geotechnical Centre of the University of Alberta, Edmonton by Arenson 
et al., (2005). The sampled Devon silt was passed over a No. 40 sieve $(0.425 \mathrm{~mm})$, to remove coarse sand particles present in the naturally occurring silt. Figure 1 shows the grain-size distribution for the silt material before and after sieving.

\section{SUMMARY OF LABORATORY TESTING PROGRAMS}

The present laboratory testing program has been conducted with the primary objective of: (i) measuring the evaporative fluxes from bare-soil surfaces while drying high water content soils under laboratory controlled environmental conditions; and (ii) determining the suction at which the evaporation rate begins to reduce from $P E$.

The research program presented in this section describes:

1. The laboratory equipment, and

2. The laboratory testing procedures for the measurement of the SWCC, and

3. The test program to measure the evaporative fluxes from i.) thin (i.e., 0.5 to $1.0 \mathrm{~mm}$ ), non-saline soil surfaces and ii.) soil columns (i.e., $30 \mathrm{~mm}$ ) dried under laboratory conditions.

A number of laboratory testing programs related to evaporative fluxes from bare-soil surfaces have been published in the research literature. Each test program has been carried out with specific objectives in mind. In each case there needed to be data available on water contents, relative humidity of the ambient air, temperature of the ambient air, and the temperature of the soil. It was also necessary to have an independent measurement of evaporation from a freshwater container. Datasets from the research literature were later used in this paper for verification of the proposed soil-atmosphere model. 


\section{Description of the Golder Pressure Plate Cell and the Vacuum Desiccator}

Two types of equipment were used in the laboratory testing program, namely, a Golder pressure plate apparatus and vacuum desiccators. The Golder pressure plate cells were manufactured by GCTS, Tempe, AZ. Four vacuum desiccators were purchased from Fisher Scientific.

The Golder pressure plate apparatuses were used to measure the soil-water characteristic curves from low suctions (e.g., $5 \mathrm{kPa}$ ) to $500 \mathrm{kPa}$ under low applied total stress conditions. The testing procedure was consistent with that commonly used in geotechnical engineering practice. The pressure plate cells use the axis-transition technique concept to control matric suction in the soil specimen (Fredlund and Rahardjo, 1993).

The vacuum desiccators were used to equilibrate soil specimens with saturated salt solutions. Total suctions were determined based on the vapor pressure equilibrium technique established using salt solutions. Desiccators with various saturated salt solutions in the bottom were used to establish various relative humidity environmental conditions. Total suctions were calculated based on the thermodynamic relationship between total suction and the partial pressure of the pore-water (Edlefsen and Anderson, (1943), Richards, (1965).

The salt solutions used were consistent with those listed in ASTM Designation E 104-02 (Table 2). 
The temperature in the laboratory room was found to vary between $19.5{ }^{\circ} \mathrm{C}$ to $22{ }^{\circ} \mathrm{C}$. The information in Table 2 was used for establishing high suction environments. The drying SWCCs for Ottawa sand and Devon silt are presented in Figure 2.

\section{Thin Soil Layer Drying Tests}

Two non-saline soils (i.e., Ottawa sand and Devon silt) were chosen to study the evaporation rate from thin soil layers (i.e., 0.5 to $1.0 \mathrm{~mm}$ ). The thin soil layer tests were conducted using identical $200 \mathrm{~mm}$ diameter evaporation pans. One pan contained distilled water (and served as a reference measurement for the determination of $P E$ ). The evaporation rate from each of the (non-saline) soil pans was compared to the evaporation rate from the pan containing water. The change in mass of all pans was monitored manually using a Mettler TOLEDO balance with the accuracy of $+/-0.05$ grams. Soil surface temperature and the water surface temperature were not monitored as part of this laboratory program. However, a digital Relative Humidity/Temperature Meter (Traceable) was placed $300 \mathrm{~mm}$ above the pans to record air temperature and the relative humidity on a regular basis.

All thin soil layer tests were conducted at the University of Alberta, Geotechnical Engineering laboratory NREF L2-040 between February 20 and February 24, 2012. The tests were maintained at a room temperature of approximately $20{ }^{\circ} \mathrm{C}$. Further control of the relative humidity in the room was not attempted. However, the fluctuations in the laboratory environment were noted to be minor. 
All samples were permitted to dry in the absence of any direct radiative forcing such as heat lamps or infrared bulbs. These were avoided to ensure a uniform energy budget over the surface of each evaporating soil. The overhead fluorescent room lights (Phillip F32T8/TL841 PLUS, 32 watts) were turned on for the duration of all tests.

Two sets of thin soil layer experiments were conducted on Ottawa sand and Devon silt. The thin soil layers were prepared by gently dusting a layer of dry soil onto a metal pan $200 \mathrm{~mm}$ in diameter. The dusting procedure was carried out using a hand-held sieve filled with soil. A No. 40 sieve was used for the Devon silt and the Ottawa sand. Soil was placed uniformly over the pans by gently shaking the soil-filled sieve in circular motion over the surface area of the pans. The application of soil was ceased when the soil formed a soil layer covering the bottom of the pan. The final layer thicknesses for the Devon silt and Ottawa sand were measured at the end of the test using calipers and found to vary between $0.5-1 \mathrm{~mm}$. The dry weight of Devon silt was 21.7 grams and the dry weight of Ottawa sand was 57.1 grams.

Each dry soil layer was subsequently sprayed with distilled water. The distilled water was applied to the soil in the form of a fine mist. The mist applicator was held approximately 1.0 meter above the soil surface and moved in a circular motion around the soil during the application of moisture. The misting procedure continued until free water appeared over the entire soil surface. At this point the soil was assumed to be completely saturated. The initial water content of the Devon silt was $58.3 \%$ and the initial water content of the Ottawa sand was $27.2 \%$. Each saturated soil layer was kept in a sealed Ziploc plastic bag until all 
five pans of soil were prepared. All soil specimens were exposed to evaporation at the same time.

The change in mass due to evaporation from the soil surfaces was manually recorded at regular time intervals. A 15-minute interval was used for the tests on Ottawa sand. A 20 minute interval was used throughout the tests on Devon silt. Shorter time intervals were used for the sand since it dried faster than the silt. The temperatures of the soil and water were not recorded. The air temperatures and the relative humidity of air above the soil layers were recorded each time the soils were weighed.

\section{Soil Column Drying Tests}

The soil-filled evaporation columns of Ottawa sand were contained in a plastic cylinder which had an inside diameter, ID, of $105 \mathrm{~mm}$. The wall thickness of the cylinders was 1.5 $\mathrm{mm}$. The Devon silt was contained within $75 \mathrm{~mm}$ ID mica tubes with a wall thickness of 6 mm. All soil-filled evaporation containers were cut to $50 \mathrm{~mm}$ in height. Ottawa sand, Devon silt and distilled water were placed in the cylinders to a depth of $30 \mathrm{~mm}$.

Waxed paper was placed around the inside circumference of the cylinders and across the bottom of the Devon silt specimens to prevent cracks from occurring as the soil dried. The intent was to reduce the adhesion of the silt to the sides and bottom of the cylinders. The soil-filled containers were gently tapped to produce a flat soil surface. All soil-filled containers were open at the top. Each of the specimens was weighed on a daily basis. 
Eleven replicate cylinder of Ottawa sand were prepared for the drying experiment. The Ottawa sand cylinders were sampled in a destructive manner at a specific elapsed time to obtain the profile of soil water contents. Each of the Ottawa sand cylinders were weighed at six hour intervals.

Eight replicates cylinders of Devon silt were prepared for the drying experiment. Each of the Devon silt cylinders were weighed at 12 hour intervals.

The change in mass of soil was manually recorded at the specified time intervals. A digital Relative Humidity/Temperature Meter (Traceable) was placed $300 \mathrm{~mm}$ above the soilfilled containers to record the air temperature and the relative humidity.

Destructive sampling entailed sectioning the $30 \mathrm{~mm}$ cylinders into $1 \mathrm{~mm}$ thick slices using a small spatula. The spatula was used to cut horizontal planes through the soil column. The slices were obtained at depths of $1 \mathrm{~mm}, 10 \mathrm{~mm}, 20 \mathrm{~mm}$ and $30 \mathrm{~mm}$. A ruler was used to mark off the various depths along the soil specimen. A profile of gravimetric water content was measured. The soil slices were placed on aluminum tares and kept in sealed plastic Ziploc bags until they were weighed and placed in an oven to dry.

\section{THEORETICAL DEVELOPMENT OF A SOIL-ATMOSPHERIC EQUATION FOR ESTIMATION OF ACTUAL SOIL EVAPORATION}

Wilson (1990) provided a modification to the Penman (1948) equation for the calculation of evaporation from saturated and unsaturated soil surfaces. The equation included the relative humidity at the unsaturated soil surface and was an attempt to move away from the primary limitation associated with the Penman (1948) equation. The Wilson (1990) 
equation also did not take into consideration the existence of soil "surface resistance" to the diffusion of water vapour from unsaturated pores in the soil matrix to the soilatmosphere boundary.

It became apparent over time that the Wilson-Penman (1990) equation over-estimated actual evaporation from unsaturated soil columns (Dunmola, 2012; Tran, 2013). A new soil-atmosphere equation was derived that made use of routinely measured weather parameters and took soil "surface resistance" into consideration. The Penman-Monteith (1965) equation includes a term that can be used to simulate soil "surface resistance" and in this way it differs from the Penman (1948) equation. Consequently, the PenmanMonteith (1965) equation is better suited for modifications that accommodate the calculation of $A E$ from unsaturated soils in arid regions.

Several assumptions were made when proposing modifications to the Penman-Monteith (1965) equation. The modified Penman-Monteith equation is used to describe the soilatmosphere boundary condition that accommodates the movement of water vapor.

1. The atmosphere in the turbulent layer immediately above a soil surface is in a neutral condition, consequently, the profile of wind speed can be expressed as a Natural Logarithmic function;

2. Soil "surface resistance" exists at the top of the soil surface where water vapor diffusion dominates;

3. The air adjacent to the evaporating front is assumed to lie within $0-1 \mathrm{~cm}$ below the soil surface (van de Griend and Owe, 1994) and is not in equilibrium with liquid water in soil 
pores. In other words, thermodynamic equilibrium laws are invalid in this layer as soil dries.

The evaluation of evaporative flux from a soil surface requires detailed information regarding atmospheric stability, surface roughness, wind speed and surface temperature. The combination method (i.e., energy balance equation and mass balance equation) at ground surface was used in the derivation of the equation commonly referred to as the Penman-Monteith (1965) equation (Monteith, 1965):

$$
E_{A}=\frac{\Gamma Q+\eta \frac{f^{\prime}(u)}{f(u)} E_{a}^{\prime}}{\Gamma+\eta A \frac{f^{\prime}(u)}{f(u)}}
$$

where: $E_{a}=$ flux associated with "mixing", $E_{a}=f(u) e_{a}(B-A) ; f(u)=$ a function depending on wind speed, roughness and turbulence condition; $f(u)=3.5\left(1+0.146 U_{a}\right) ; U_{a}=$ wind speed, km/hr; $e_{a}=$ air pressure in the air above soil surface, $(\mathrm{kPa}) ; Q_{n}=$ heat budget, (mm/day); $\Gamma=$ slope of the saturation vapour pressure versus temperature curve at the mean temperature of the air, $\left(\mathrm{Pa} /{ }^{\circ} \mathrm{C}\right) ; \eta=$ psychrometric $\quad$ constant, $66.8 \quad\left(\mathrm{~Pa} /{ }^{\circ} \mathrm{C}\right)$; $\frac{f^{\prime}(u)}{f(u)}=1+\frac{r_{s}}{r_{a v}}$ which is derived from the concept of a two-step evaporation process (e.g., molecular diffusion and turbulent diffusion), and the "similarity theory" (Monteith, 1965). Further details related to the derivation can be found in Tran (2013). 
Equation [2] describes evaporation from a soil surface on the basis of net radiation, wind speed, relative humidity of the air and the soil surface, and soil "surface resistance". Details pertaining to soil "surface resistance" are discussed in the following sections.

Equation [2] reduces to conventional Penman (1948) equation when $A=$ unity (i.e., relative humidity of 100 percent for a saturated surface) and surface resistance is assumed to be zero. It is also interesting to note that Eq. [2] reduces to the Wilson (1990) equation when $f^{\prime}(u) / f(u)=1$ (i.e., the transmission functions for mass and heat are assumed to be the same or the soil "surface resistance" is equal to zero). Equation [2] contains not only a component of relative humidity at the soil surface, but also soil "surface resistance". It indicates that the evaporation rate will decrease during the drying process as the relative humidity of the soil surface decreases and the soil surface resistance increases.

\section{ASSESSMENT OF SUCTION AT "EVAPORATION-RATE REDUCTION POINT" DURING DRYING PROCESS}

The field capacity of a soil (i.e., in terms of volumetric water content) has been previously used to assess not only soil "surface resistance", but also the relative humidity at soil surfaces (Kondo et al., 1990; Lee and Pielke, 1992; van de Griend and Owe, 1994; Aluwihare and Watanabe, 2003; Bittelli et al., 2008). Field capacity has been applied in several disciplines (e.g., hydrology and agricultural engineering) and while it corresponds to an applied matric suction of approximately $1 / 3$ atmosphere, the soil may either be 
saturated or unsaturated depending upon the texture of the soil. Field capacity has not been accepted as a meaningful soil parameter in geotechnical engineering applications. Rather, soil suctions associated with distinct degree of saturation points on the SWCC have been more widely accepted within geotechnical and geo-environmental engineering as being more closely related to the evaporation rate from a soil surface.

An equation was derived that took into consideration the suction at which the evaporation rate from a soil surface begins to reduce from PE. The suction at which evaporation reduces should be related to parameters associated with the drying SWCC of the soil (e.g., the air-entry value, $\psi_{\text {aev }}$ and/or residual soil suction, $\left.\psi_{\text {res }}\right)$.

The present study involved the re-assessment of thin soil section drying tests as well as soil column drying tests. Datasets from other drying column tests published research literature were also analyzed. The empirical procedures proposed by Fredlund et al., (2012) were used to define the suction and water content at the air-entry of the soil as well as at residual conditions. The objective was to determine the suction and corresponding water content at which evaporation begins to reduce from potential evaporation.

\section{Re-assessment of Thin Soil Layer Drying Tests Collected from the Literature}

Nine thin soil layer drying tests were performed on Beaver Creek sand, Custom silt and Regina clay by Wilson (1990). Along with measuring the ratio $A E$ / $P E$, the relative humidity of the air, the soil-water content, the temperature of the air, soil and water were continuously measured during the drying process. It was observed that the ratio of $A E / P E$ 
started to reduce from unity when the gravimetric water content reached approximately 2 , 5 and 20 percent for the Beaver Creek sand, Custom silt and Regina clay, respectively. These above-mentioned values of water content can be converted to suction values on the drying SWCCs. The observed (drying curve) residual suctions are $6.5 \mathrm{kPa}, 40 \mathrm{kPa}$ and $925 \mathrm{kPa}$ for Beaver Creek sand, Custom silt and Regina clay, respectively (see Figure 3). These suctions are much lower than a total suction of $3000 \mathrm{kPa}$ where the Lord Kelvin equation would suggest that evaporation rates should start to decrease.

Figure 4 presents a comparison of the SWCC and the relative evaporation rate, $A E / P E$, for thin soil layers of Beaver Creek sand tested by Wilson (1990). The results show that as long as the soil surfaces were kept at or near saturation and the total suction was lower than $3,000 \mathrm{kPa}$, evaporation was controlled by laboratory room conditions (i.e., referred to as Stage I of the evaporation process). The evaporating front appeared to be near the surface of the thin soil specimens. In the case of a thin soil layer, the distance for the vapour to travel to the soil-atmosphere interface was negligible. In other words, there was little flow of liquid water or water vapour diffusion to the soil surfaces.

The water in thin soil layers is in contact with the atmosphere above the soil. In other words, air close to the pore-water surface was in equilibrium with the pore-water. Consequently, the Lord Kelvin's equation is valid for the simulation of the drying process in thin soil layers. For these reasons, it can be concluded that the actual rate of evaporation from thin layers of the three soil types starts to reduce from the potential rate of evaporation as total suction exceeds $3,000 \mathrm{kPa}$. 
Other independent drying tests on thin soil layers, (i.e., $2 \mathrm{~mm}$ thick layer of silt), were carried out by Dunmola (2012). The experimental results are similar to the thin soil layer tests by Wilson (1990). The results are plotted in Figure 5 and show a "breaking point" near a total suction of $3,000 \mathrm{kPa}$.

\section{Re-assessment of Soil Column Drying Tests Collected from the Literature}

Several evaporation rate studies on soil columns have been performed and these results can be re-assessed. The following soil test columns were selected for re-assessment: i.) Columns A and B on Beaver Creek sand by Wilson (1990), ii.) soil columns of Beaver Creek sand, Processed silt and Natural silt tested by Bruch (1993), and iii.) coarse sand and fine sand columns tested by Yanful and Choo (1997).

The results from the soil column drying test on sand carried out by Wilson (1990) showed that the rate of actual soil evaporation begins to reduce from the potential rate of evaporation at a total suction of approximately $5 \mathrm{kPa}$, a value well below a total suction of $3,000 \mathrm{kPa}$. The results show that the soil surface was maintained at or near saturation provided the total soil suction at the surface is kept lower than about $5 \mathrm{kPa}$ for the Beaver Creek sand. The corresponding water content generated from the SWCC on Beaver Creek sand was found to be 11 percent which is higher than the water content of approximately 2 percent when the thin soil layers showed a reduction in evaporation rate.

The findings appear to be similar for evaporation tests on the Beaver Creek sand, Processed silt and Natural silt conducted by Bruch (1993). The suction values at the ERRP were found to be $7 \mathrm{kPa}, 62 \mathrm{kPa}$ and $116 \mathrm{kPa}$ for Beaver Creek sand, Processed 
silt and Natural silt, respectively. These values are well below a total suction of 3,000 $\mathrm{kPa}$. The results indicate that the soil surfaces are maintained at or near saturation provided the soil suctions at the surface are kept lower than values of $7 \mathrm{kPa}, 62 \mathrm{kPa}$ and $116 \mathrm{kPa}$ for the Beaver Creek sand, Processed silt and Natural silt, respectively. The corresponding water contents at the ERRP determined from the SWCCs are 11, 10 and 9 percent for the Beaver Creek sand, Processed silt and Natural silt, respectively. Details of the ERRP analysis can be found in Tran (2013).

Soil suction increases at the soil surface during the process of drying. The air-entry value is the point where air begins to enter the largest soil pores at the soil surface. Water vapour is present above the soil while the liquid water phase is continuous. Evaporation at this point is still dependent upon liquid water being able to flow upward to the soil surface. Evaporation under these conditions is essentially equal to $P E$. Soil suction continues to increase as drying occurs and approaches a suction value equal to the ERRP.

The suction at which the evaporation rate notably reduces can be designated using a new suction variable, $\psi_{R}$. For each soil examined, the value of $\psi_{R}$ was found to be between the air-entry value and the residual soil suction value. At the ERRP, the conductive properties of the soil no longer permit a sufficient flow of water to reach the soil surface in order to maintain the potential rate of evaporation. As a result, water is not in contact with the atmosphere; hence, the Lord Kelvin's equation is no longer valid for drying soils. The soil surface then becomes sufficiently desiccated to cause the liquid-water phase to 
become discontinuous. These suction values appear to be quite close to the residual suction for each soil.

Water appears to be transferred to the soil surface mainly through the diffusion of water vapour once the water phase becomes discontinuous. In other words, the addition of water to the surface appears to be dominated by the process of vapour diffusion (i.e., Stage II of the evaporative process). This phenomenon applies when the soil suction is between the suction at the ERRP and residual soil suction. Eventually the flow of liquidwater to the surface may cease and the evaporation may take place only under vapour diffusion (i.e., Stage III of the evaporative process).

Air-entry values, residual suctions as well as soil suctions at the ERRP can be determined from the drying SWCC tests published in the research literature. The evaporative datasets for the Beaver Creek sand columns A and B tested by Wilson (1990); the Beaver Creek sand column, Processed silt column and Natural silt column tests by Bruch (1993); the coarse sand and fine sand columns tested by Yanful and Choo (1997), can be reassessed. Accordingly, soil suction at the ERRP was independently compared to the airentry value and residual suction values for each of the soils tested. The results from the above-mentioned column tests are plotted in Figures 6 and 7.

\section{Equation for Determination of Suction at the Evaporation-Rate Reduction Point}

Reductions in evaporation rates can be assessed from data on a series of soil column tests described in the research literature. The suction at the ERRP appears to occur between the air-entry value and the residual soil suction. The SWCC for soils vary on a 
logarithmic suction scale. It seems reasonable that the "evaporation-rate reduction" point would also vary on a logarithmic scale. The following empirical equation is proposed for quantifying the ERRP.

$\psi_{R}=\left\{\begin{array}{cc}\psi_{\text {aev }} & \text { if } a=0 \\ \psi_{\text {res }} & \text { if } a=1 \\ \psi_{\text {res }}^{a} \times \psi_{\text {aev }}^{1-a} & \text { if } 0<a<1\end{array}\right.$

where: $\psi_{R}=$ suction at the ERRP, $\mathrm{kPa} ; \psi_{\mathrm{aev}}=$ air-entry value determined from the drying SWCC, $\mathrm{kPa} ; \psi_{\text {res }}=$ residual soil suction determined from SWCC, $\mathrm{kPa} ; \mathrm{a}=$ an empirical factor varying between 0 and 1.

Equation [3] quantifies the suction at the ERRP which appears to occur between the airentry value and residual soil suction of a soil. In order to find the best-fitting value for "a", two sets of evaporation data were analyzed; one for sand and other for silt. Coefficients of determination and R-squared were used as a measure of the fit calculated using Eq. [3] for various values of the power, "a". Values of "a" equal to 0.6 and 0.75 were found to optimize the ERRP suction, $\psi_{R}$ for sand and silt, respectively (Tran, 2013).

\section{DEVELOPMENT OF THE VAPOUR PRESSURE AND SOIL “SURFACE RESISTANCE” AT THE SOIL SURFACE}

The vapour pressure and soil "surface resistance" properties of a soil are dependent upon the volumetric water content corresponding to the ERRP. 


\section{Determination of Volumetric Water Content at Evaporation-Rate Reduction Point}

The soil-water characteristic curve is a nonlinear relationship between soil suction and soil water content. Numerous equations have been proposed to mathematically fit the soilwater characteristic curves (Fredlund and Xing, 1994; van Genuchten, 1980). The Fredlund and Xing (1994) equation was used for the analysis of data in this paper. The suction at ERRP, $\psi_{R}$ can be determined using Eq. [3]. The corresponding volumetric water content, $\theta_{R}$ can be determined from the SWCC.

\section{Estimation of Vapour Pressure and Relative Humidity at the Soil Surface Based on the Volumetric Water Content at the "ERRP"}

A method was proposed by Lee and Pielke (1992) for the prediction of the relative humidity at the soil surface. The equation introduced a soil moisture availability factor, $\beta$. One of the main disadvantages associated with the proposed Lee and Pielke (1992) equation was the introduction of field capacity as a reference point. It would appear to be more appropriate to use the air-entry value and residual suction conditions when dealing with problems in geotechnical engineering practice. In other words, field capacity does not adequately quantify the desaturation characteristics of a soil. It is therefore suggested that the field capacity term in the Lee and Pielke (1992) equation be replaced with the volumetric water content at the ERRP. The following equations for soil moisture availability factor, $\beta$; and hence relative humidity are suggested as an improved way of determining the vapour pressure at the soil surface. 
$\beta= \begin{cases}\frac{1}{4}\left[1-\cos \left(\frac{\theta}{\theta_{R}} \pi\right)\right]^{2} & \theta<\theta_{R} \\ 1 & \theta \geq \theta_{R}\end{cases}$

where: $\beta=$ coefficient representing the surface moisture availability; $\theta_{R}=$ volumetric water content at the ERRP; $\theta=$ volumetric water content of the soil in the top $1 \mathrm{~cm}$ of the soil column.

The actual water vapour pressure at the soil surface is determined from the soil moisture availability factor, $\beta$. The soil moisture availability factor equation has been derived from consideration of the evaporation rate from bare soil surfaces (Kondo et al., 1990).

$$
p_{v}=\beta p_{v}^{\text {sat }}+(1-\beta) p_{v}^{a i r}
$$

where: $p_{v}=$ actual vapour pressure at the soil surface, $\mathrm{kPa} ; p_{v}^{\text {sat }}=$ saturated vapour pressure at the soil surface, $\mathrm{kPa} ; p_{v}{ }^{a i r}=$ air vapor pressure immediately above the soil surface, kPa.

The relative humidity, $R H$, is the ratio of the actual vapor pressure to saturated vapor pressure at the same surface temperature.

$$
R H=\frac{p_{v}}{p_{v}^{s a t}}
$$

\section{Soil "Surface Resistance" to Actual Evaporation}

An exponential equation of soil "surface resistance" was proposed by van de Griend and Owe (1994) and has been selected for minor modification for the proposed actual evaporation formulation. The van de Griend and Owe (1994) equation was based on the 
measurements of soil "surface resistance" when using a fast-air circulation chamber. The van de Griend and Owe (1994) equation was written as follows for a sandy soil:

$$
r_{s}=10 \times e^{0.3563\left(\theta_{\min }-\theta_{\text {top }}\right)}
$$

where: $r_{s}=$ soil "surface resistance" at top $0-1 \mathrm{~cm}, \mathrm{~s} / \mathrm{m} ; \theta_{\text {top }}=$ volumetric water content of the top $1 \mathrm{~cm}$ layer, (\%); $\theta_{\min }=$ an empirical minimum above which the soil is able to deliver vapour at a potential evaporation rate, (\%). A value of $\theta_{\min }$ equal to $15 \%$ was suggested by van de Griend and Owe (1994).

One disadvantage of the van de Griend and Owe (1994) model was the use of a fixed $\theta_{\min }$ value of 15 percent as a reference point. It is suggested that $\theta_{\min }$ should be replaced with a volumetric water content value corresponding to the ERRP, $\theta_{R}$. The value of $\theta_{R}$ can be made dependant upon soil texture through quantification of the suction at the ERRP, $\psi_{R}$. The following modified form of the van de Griend and Owe (1994) equation is proposed for the computation of soil "surface resistance".

$r_{s}=10 \times e^{0.3563\left(\theta_{R}-\theta_{t o p}\right)}$

where: $r_{s}=$ soil "surface" resistance in the top $0-1 \mathrm{~cm}, \mathrm{~s} / \mathrm{m} ; \theta_{\text {top }}=$ volumetric water content of the top $1 \mathrm{~cm}$ layer, (\%); $\theta_{R}=$ volumetric water content value at the ERRP, $(\%)$, which is determined from the suction at the ERRP, $\psi_{R}$ (Eq. [3]).

\section{VERIFICATION USING THE DATA FROM THE LABORATORY PROGRAM}

The proposed theory for $A E$ was verified using drying thin soil layers (i.e., $1 \mathrm{~mm}$ thick) test results and the soil columns (i.e., $30 \mathrm{~mm}$ thick) test results. The soils tested were Ottawa 
sand and Devon silt. Measurements of evaporative fluxes along with the soil-water content and enviroment data are presented in Tran (2013).

The water content at a total suction of $3,000 \mathrm{kPa}$ was determined from the SWCC for the non-saline Ottawa sand and Devon silt to be approximately 0.35 percent and 22 percent, respectively (see Figure 2). The soil-water moisture availability factor, vapour pressure and soil "surface resistance" at the soil surface were calculated using Eq. [4], Eq. [5] and Eq. [8], respectively. The rate of evaporation was calculated using Eq. [2]. The aerodynamic resistance to turbulent diffusion, $r_{a v}$, ranged between 316 and 365 s/m for the Ottawa sand column tests and ranged between 296 and 344 for the Devon silt column test.

Figure 8 shows a plot of the potential evaporation rate ( $P E$ - Measured) from a water surface, the measured actual evaporation rate ( $A E$ - Measured) from the sand surface and the calculated evaporation rate $(A E$ - Calculated) for thin non-saline Ottawa sand. The calculated evaporation rates agree well with the measured evaporation rates. The soil "surface resistance" for thin soil layers has a maximum value of approximately $11 \mathrm{~s} / \mathrm{m}$ under dry soil surface conditions.

Figure 9 shows the calculated, actual and potential evaporation rates for the thin layers of Devon silt. The figure shows that the calculated evaporation rate does not agree well with the measured evaporation rates. The agreement is not as close for the Devon silt as it was for Ottawa sand. There appears to be a slight offset for the calculated evaporation rates. The calculated evaporation rate, for example, falls below the potential evaporation 
rate at an earlier time than does the actual evaporation rate. It should be noted that the residual suction (i.e., $12,600 \mathrm{kPa}$ ) is larger than the value of $3,000 \mathrm{kPa}$ where the Lord Kelvin equation would suggest there would be a reduction in evaporation rate.

Devon silt had a gravimetric water content of $22 \%$ at a total suction of $3000 \mathrm{kPa}$. This value is higher than the residual water content which was 5 percent (See Figure 2) Consequently, a lower vapour pressure is computed at the soil surface and hence a lower rate of evaporation. A maximum soil "surface resistance" of approximately 2,900 s/m was computed at the end of the test. This value is too large for a thin drying layer of silt soil.

Figure 10 shows the calculated, actual and potential evaporation rates for the Devon silt using a water content of 5 percent as the reference point for the soil moisture availability factor at the soil surface. The figure shows reasonably good agreement between the calculated and measured actual evaporation rates. However, a discrepancy is noted near the end of the test when the soil evaporation approaches zero. For example, an evaporative flux of $0.26 \mathrm{~mm} /$ day was computed when the measured evaporation was approaching zero. The discrepancy is small and is likely attributable to experimental errors associated with the measurement of water content, temperature of the soil, water and air, and relative humidity of the air. A maximum soil "surface resistance" of approximately 20 $\mathrm{s} / \mathrm{m}$ was computed at the end of the test. This value is reasonable for the drying thin layer of soil.

Verification of the drying soil column (i.e., $30 \mathrm{~mm}$ thick) tests for Ottawa sand and Devon silt are also presented in this section. The suction at ERRP for both Ottawa sand and 
Devon silt was obtained using Eq. [3] and found to be approximately $12 \mathrm{kPa}$ and 4,380 $\mathrm{kPa}$, respectively. The corresponding water contents at the ERRP generated from the SWCCs of the Ottawa sand and Devon silt as shown in Figure 2 were 7 and 17 percent, respectively. The soil moisture availability factors, vapour pressure and soil "surface resistance" at the soil surface were calculated using Eq. [4], Eq. [5] and Eq. [8], respectively. The evaporative fluxes for the thick soil layers were computed using Eq. [2]. Water contents at the soil surface were recorded along with the evaporative fluxes. The evaporation rates could be computed. It should be noted that the soil water contents used in Eq. [4] were taken in the uppermost $1 \mathrm{~cm}$ of the soil column.

Figures 11 and 12 show the calculated, actual and potential evaporation rates for the Ottawa sand and Devon silt, respectively. Both figures show reasonably good agreement between the calculated and measured actual evaporation rates. This indicates that the rate of evaporation from the soil columns likely begins to decline at total suction lower than residual suction. The soil "surface resistance" for the sand and silt varies from zero at high water content to few hundreds as the soil dries. For example, soil "surface resistance" varies from zero to $331 \mathrm{~s} / \mathrm{m}$ and $361 \mathrm{~s} / \mathrm{m}$ for the Ottawa sand and Devon silt, respectively. The calculated soil "surface resistance" values are consistent with those reported in the research literature (van de Griend and Owe, 1994). The observed behaviour indicates the existence of soil "surface resistance" with water vapour diffusion occurring from a depth of $1 \mathrm{~cm}$ to the soil-atmosphere interface.

In summary, the calculated and laboratory results for the soil column drying tests demonstrate two basic principles that are important when evaluating evaporation from soil 
columns; first, evaporation begins to decline at a suction value between the air-entry value and residual soil suction, and, second, soil "surface resistance" to the diffusion of water vapor exists at a depth of $0-1 \mathrm{~cm}$ as soil dries.

\section{VERIFICATION OF EVAPORATION DATA COLLECTED FROM THE RESEARCH LITERATURE}

The new soil-atmosphere flux equation, (i.e., Eq. [2]) can also be verified using data presented in the research literature. The two procedures used in the verification process are presented in Figure 13. The calculated results obtained from these procedures are observed and discussed in the following sections.

Evaporative fluxes from soil columns were numerically computed using ComSolMultiphysics software (i.e., finite element method based analysis) when using the first procedure. The moisture flow equation was solved in a 1-D manner on a soil profile with respect to space and time. The procedure can be referred to as an uncoupled moisture flow analysis. The computed results for evaporative flux from this simulation are referred to as $A E-$-ComSol in the following figures.

The input data for the equation of moisture flow consisted of the observed microclimate parameters and the soil properties. A summary of the soil properties used in the verification analysis associated with the new proposed soil-atmosphere flux equation is provided in Table 3. The Fredlund and Xing (1994) equation was used to fit measured data for the SWCC. The coefficient of water storage was computed as a derivative of the 
volumetric water content SWCC. The unsaturated hydraulic conductivity was determined along with the assumption that the lower limit was $10^{-14} \mathrm{~m} / \mathrm{s}$ (Ebrahimi et al., 2004). The unsaturated hydraulic conductivity curve for the soil columns A and B (Wilson, 1990) was determined using the input data of saturated hydraulic conductivity of $3 \times 10^{-5} \mathrm{~m} / \mathrm{s}$ (see Table 3) and the SWCC for the Beaver Creek sand (see Figure 3). The Brooks and Corey method (1964) was used for the drying tests performed by Bruch, (1993) and Yanful and Choo, (1997). The suction value at a break point of the unsaturated hydraulic conductivity function was used as proposed by Brooks and Corey (1964). The suction value at the break point was chosen as $10 \mathrm{kPa}$ for the silt soil (Gitirana, 2005). The molecular diffusivity of water vapour in air was taken as being equal to $2 \times 10^{-14} \mathrm{~m} / \mathrm{s}$ (Kimball et al., 1976).

The partial vapour pressure for the soil-atmosphere flux equation was determined using proposed Eq. [3], Eq. [4] and Eq. [5] associated with the water content at the soil surface. Mean daily air temperature and relative humidity in the environmental chamber were used to determine the vapour pressure of the air. Potential rates of evaporation and water surface temperatures were used to determine the net radiation from a free water surface according to the Penman's equation (1948). Net radiation from the soil surface was assumed to be equal to that from an adjacent water surface. A zero flux boundary was specified for both liquid and vapour flow at the bottom of the column base. For the experiments (i.e., Beaver Creek sand, Processed silt and Natural silt) conducted by Bruch (1993), a constant head boundary condition (CHBC) (so-called Phase 1) was set for the first 30 days, and then a zero flux boundary condition (ZFBC) (so-called Phase 2) was turned on at the bottom of the soil column until the end of the drying test. Finally, the flux 
of water vapour to the atmosphere was computed using the vapour transfer profile by Eq. [2].

The evaporative fluxes in the second procedure were analyzed using an Excel Spreadsheet. The measured water contents and temperatures at or near the soil surface on specific days were used as input data in Eq. [2]. The computed results are denoted as $A E-$ Excel.

The calculated evaporative fluxes, $A E$ - ComSol and $A E$ - Excel are compared to the measured evaporative fluxes collected from the drying experiments by Wilson (1990), Bruch (1993) and Yanful and Choo (1997). Reasonably close agreement was observed between the calculated results and the experimental results for the column tests conducted by Wilson, (1990), and Yanful and Choo (1997) The results are shown in Figures 14, 18 and 19.

For the column tests conducted by Bruch (1993) and presented in Figures 15, 16 and 17, the results of the numerical model do not agree well with the measured data in Stage 1. The evaporation rates are close to the potential evaporation rate in accordance with the large hydraulic conductivity of the soil. In Stage 2, the result are in reasonable agreement since the unsaturated hydraulic conductivity tends to reach a lower limit of $10^{-14} \mathrm{~m} / \mathrm{s}$. The result from the $A E$ - Excel simulation shows reasonable agreement with the measured data for both phases. 


\section{SUMMARY AND CONCLUSIONS}

This paper presents the results of an analysis of suctions at the ERRP, for both thin soil layers and soil columns. The results show that the rate of evaporation begins to decline at total suctions approximately equal to $3,000 \mathrm{kPa}$ when the soil is placed in thin soil layers. However, the soil suction at the ERRP for the thick soil layers or soil columns was found to lie between air-entry value and residual soil suction.

An empirical equation for the determination of soil suction at the ERRP has been developed. The formulation of ERRP equation was based on assessments of the suction at the ERRP for soil columns data collected from the research literature. The values for soil suction predicted by the proposed equation were used to compute the rate of evaporation from thin soil layers and soil columns. The computed results agree reasonably well with the measured results from both soil column drying tests on Ottawa sand and Devon silt. The computed results also agree reasonably well for soil column drying test results reported in the research literature. It follows that vapour pressure, relative humidity and soil "surface resistance" depend on the water content corresponding to the suction at the evaporation-rate reduction point.

The difficulties in predicting the evaporation rate from unsaturated soil surface are related to difficulties in estimating the actual vapour pressure at the soil surface. It is suggested that the equation for actual vapour pressure at the soil surface be modified as shown in Eq. [5]. Further field verification experiments are important in completing the verification process for calculating $A E$. 
The soil "surface resistance" has been demonstrated to affect evaporation particularly at Stages II and III of the drying process. It recommended that the Penman-Monteith (1965) equation be extended as shown in the proposed equations to include the effect of soil "surface resistance".

It is also recommended that the proposed equation for suction at the evaporation-rate reduction point be further verified with future studies. The proposed equation is limited to sand and silt type soils. More studies of evaporation from various textured soils should be undertaken. The studies are also involve the assessment of shrinkage and cracking on the rate of evaporation.

\section{LIST OF REFERENCES}

Aluwihare, S., and Watanabe, K. 2003. Measurement of evaporation on bare soil and estimating surface resistance. Journal of Environmental Engineering, Vol. 129, No. 12, pp. $1157-1168$.

Alvenas, G., and Jansson, P.E. 1997. Model for evaporation, moisture and temperature of bare soil: calibration and sensitivity analysis. Agricultural and Forest Meteorology, Elsevier Science, Vol. 88, pp. 47-56.

Arenson, L., Xia, D., Biggar, K., and Sego, D. 2005. Freezing process in Devon silt-Using time laps photography. Proceedings of the Fifty Eighth Canadian Geotechnical Conference, Saskatoon, SK., Canada. 
Bittelli, M., Ventura, F., Campbell., G., Snyder, R., Gallegati., F. and Pisa, P. 2008. Coupling of heat, water vapor and liquid water fluxes to compute evaporation in bare soils. Journal of Hydrology, Vol. 362, pp. 191-205.

Brooks, R.H. and Corey, A.T. 1964. Hydraulic properties of porous media, Colorado State University, Hydrology Paper No. 3, Fort Collins, CO.

Bruch, P.G. 1993. A laboratory study of evaporative fluxes in homogeneous and layered soils. Master of Science Thesis, University of Saskatchewan, Saskatoon, SK., Canada.

Camillo, P.J., and Gurney, R.J. 1986. A resistance parameter for bare-soil evaporation models. Soil Science, Vol. 141, No. 2, pp. 95-105.

Dunmola, A. S. 2012. Predicting evaporative fluxes in saline soil and surface-deposited thickened mine tailings. Ph.D. Thesis, Department of Civil and Environmental Engineering, Carleton University, Ottawa, Ontario, Canada.

Ebrahimi-Birang, N., Gitirana Jr., G. F. N., Fredlund, D. G., Fredlund, M. D. and Samarasekera, L. 2004. A lower limit for the water permeability coefficient. Proceedings of the $57^{\text {th }}$ Canadian Geotechnical Conference, Quebec City, October 24-27. Vol. 1, pp. 1219. 
Edlefsen, N. E., and Anderson, A. B. C. 1943. Thermodynamics of soil moisture, Hilgardia, Vol. 15, No. 2, pp. 31-298.

Fen Shu, S. 1982. Moisture and heat transport in a soil layer forced by atmospheric conditions. Master of Science Thesis, University of Connecticut, USA.

Fredlund, D.G. and Rahardjo, H. 1993. Soil mechanics for unsaturated soils. John Wiley \& Sons, Inc., New York, N.Y. 517p.

Fredlund, D. G., Rahardjo, H., and Fredlund, M. D. 2012. Unsaturated soil mechanics in engineering practice. John Willey \& Sons, Inc., Hoboken, New Jersey, USA. 926p.

Fredlund, D. G. and Xing, A. 1994. Equations for the soil-water characteristic curve. Canadian Geotechnical Journal, Vol. 31, pp. 521-532.

Fredlund, M. D. Zhang, J. M., Tran, D., and Fredlund, D. G. 2011. Coupling heat and moisture flow for the computation of actual evaporation. Paper No. 1058, Proceedings of the Canadian Geotechnical Conference and Fifth Pan-American Conference, Toronto, ON, Canada. October 2-6.

Gitirana Jr., G. F. N. 2005. Weather-related geo-hazard assessment model for railway embankment stability. PhD thesis, Department of Civil Engineering, Saskatoon, SK,m Canada, $411 \mathrm{p}$. 
Kimball, B.A., Jackson, R.D., Reginato, R.J., Nakayama, F.S. and Idso, S.B. 1976. Comparison of field-measyred and calculated soil-heat fluxes, Soil Science Society of America Proceedings, Vol. 40, No. 1, pp. 18-26.

Kondo, J., Saigusa, N., and Sato, T. 1990. A parameterization of evaporation from soil surfaces. Journal of Applied Meteorology, American Meteorological Society, Vol. 29, pp. 385-389.

Krahn, J., and Fredlund, D. G. 1972. On total, matric and osmotic suction. Journal of Soil Science, Vol. 114, No. 5, pp. 339-348.

Lee, T. J., and Pielke, R. 1992. Estimating the soil surface specific humidity, Notes and Correspondence. Journal of Applied Meteorology, American Meteorological Society, Vol. 31, pp. 480-484.

Mahfouf, J. F., and Noilhan, J. 1991. Comparative study of various formulations of evaporation from bare soil using in-situ data. Journal of Applied Meteorology, American Meteorological Society, Vol. 30, pp. 1354-1365.

Mihalovi'c, D. T., Pielke, R. A., Rajkovi'c, B., Lee, T. J., Jefti'c, M. 1993. A resistance representation of schemes for evaporation from bare and partly plant-covered surfaces for use in atmospheric models. Journal of Applied Meteorology, Vol. 32, pp. 1038-1054. 
Monteith, J. L. 1965. Evaporation and the environment. In the movement of water in living organisms. XIX Symposium Society for Experimental Biology, Swansea, Cambridge, University Press, Vol. 19, pp. 205-234.

Penman, H. L. 1948. Natural evapotranspiration from open water, bare soil and grass. Proceedings of the Royal Society of London, Series A193, pp. 120-145.

Philip, J. R. 1957. The theory of infiltration: the infiltration equation and its solution. Journal of Soil Science, Vol. 83, pp. 345-357.

Richards, B. G. 1965. Measurement of the free energy of soil moisture by the psychrometric technique using thermistors. Moisture Equilibria and Moisture Changes in Soils Beneath Covered Areas, A Symposium in Print, Butterworths, Sydney, pp. 39-46.

Tran, D. T. Q. 2013. Re-Visitation of actual evaporation theories. Ph.D. Thesis, University of Alberta, Edmonton, AB., Canada.

van de Griend, A. A., and Owe, M. 1994. Bare soil surface resistance to evaporation by vapor diffusion under semiarid conditions. Water Resources Research, Vol. 30, No. 2, pp. $181-188$.

van Genuchten, T. M. 1980. A closed-form equation for predicting the hydraulic conductivity of unsaturated soils. Journal of Soil Science Society of America, Vol. 44. 44, pp. 892-898. 
Wilson, G. W. 1990. Soil evaporative fluxes for geotechnical engineering problems. Ph.D. Thesis, University of Saskatchewan, Saskatoon, SK., Canada.

Wilson, G. W., Barbour, S. L., and Fredlund, D. G. 1997. The effect of soil suction on evaporative fluxes from soil surfaces. Canadian Geotechnical Journal, Vol. 34, No. 1, pp. $145-155$.

Yanful, E. K., and Choo, L. P. 1997. Measurement of evaporative fluxes from candidate cover soils. Canadian Geotechnical Journal, Vol. 34, pp. 447-459. 


\section{List of Figures}

Figure 1: Grain-size distributions for Devon silt before and after passing through No. 40 sieve.

Figure 2: Drying soil-water characteristic curves for Ottawa sand and Devon silt using the Fredlund and Xing (1994) fitting curves.

Figure 3: $\quad$ Fredlund and Xing (1994) Soil-water characteristic curves for the sand, silt and clay (from Wilson 1990).

Figure 4: Extent of Stage I of the evaporative process for thin soil layers of the Beaver Creek sand (data from Wilson, 1990).

Figure 5: Illustration of extent of Stage I of the evaporative process for thin soil layers of the non-saline silt (data from Dunmola, 2012).

Figure 6: Comparison of the air-entry value, residual soil suction and suction at the ERRP (data collected from the drying experiments by Wilson, 1990; Bruch, 1993; Yanful and Choo, 1997).

Figure 7: Comparison of the air-entry value, residual soil suction and suction at the ERRP (data collected from the drying experiments by Bruch, 1993).

Figure 8: Calculated, actual and potential evaporation rates for thin non-saline Ottawa sand.

Figure 9: Calculated, actual and potential evaporation rates for thin Devon silt with the water content at a total suction of $3,000 \mathrm{kPa}$ used as a reference point for vapour pressure at the soil surface.

Figure 10: Calculated, actual and potential evaporation rates for thin layer of Devon silt using the water content at the ERRP observed during the drying test.

Figure 11: Calculated, actual and potential evaporation rates for thick Ottawa sand (i.e., $3 \mathrm{~cm}$ thick).

Figure 12: Calculated, actual and potential evaporation rates for thick Devon silt (i.e., 3 cm thick). 
Figure 13: Illustration of two procedures used in the verification of the new soilatmosphere model.

Figure 14: Calculated and measured evaporation rates for soil columns $A$ and $B$ of Beaver Creek sand (data from Wilson, 1990).

Figure 15: Calculated and measured evaporation rates for the soil column of Beaver Creek sand (data from Bruch, 1993).

Figure 16: Calculated and measured evaporation rates for the soil column of Processed silt (data from Bruch, 1993).

Figure 17: Calculated and measured evaporation rates for the soil column of Natural silt (data from Bruch, 1993).

Figure 18: Calculated and measured evaporation rates for the soil column of the coarse sand (data from Yanful and Choo, 1997).

Figure 19: Calculated and measured evaporation rates for the soil column of the fine sand (data from Yanful and Choo, 1997). 


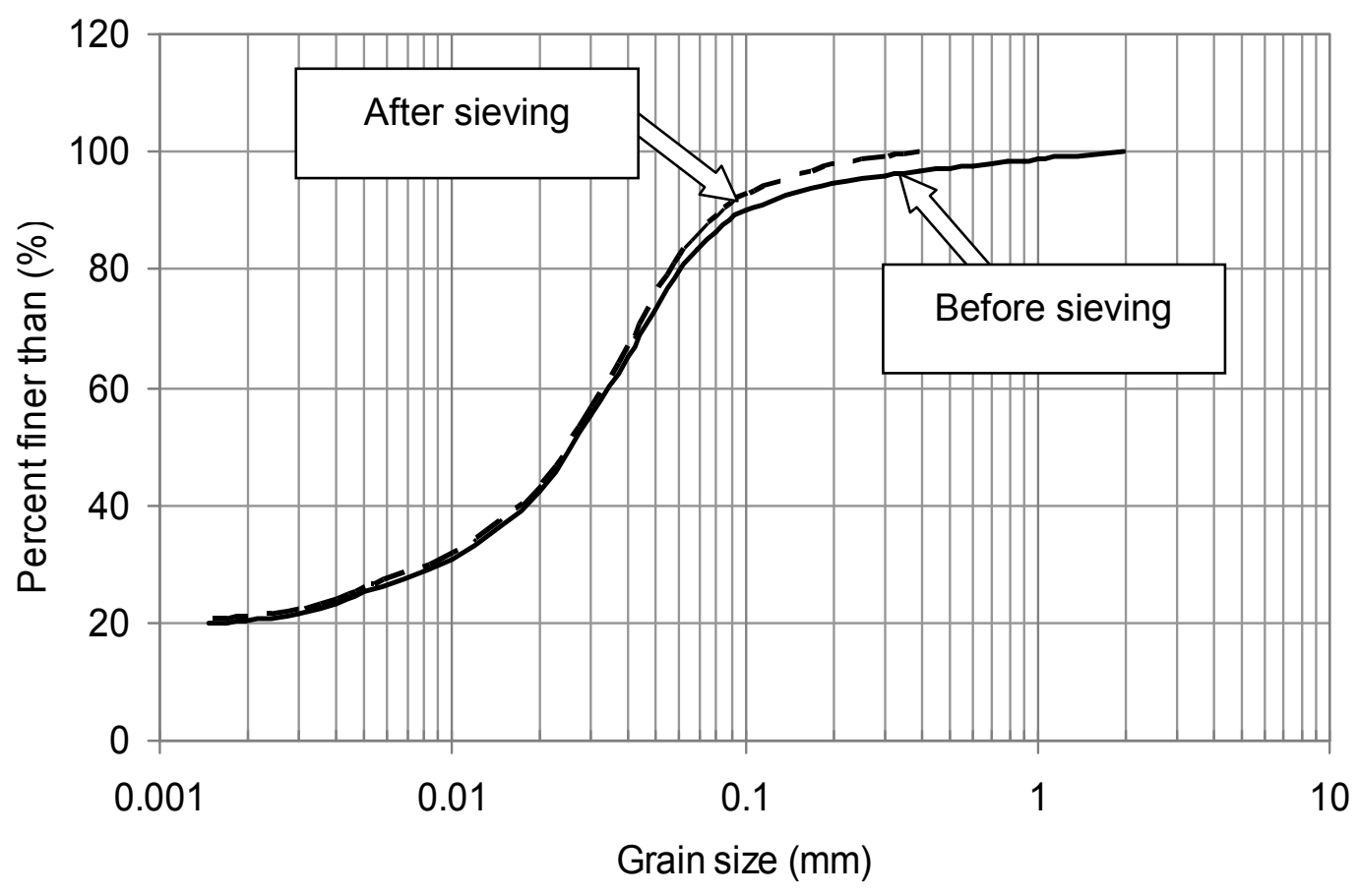

Figure 1: Grain-size distributions for Devon silt before and after passing through No. 40 sieve.

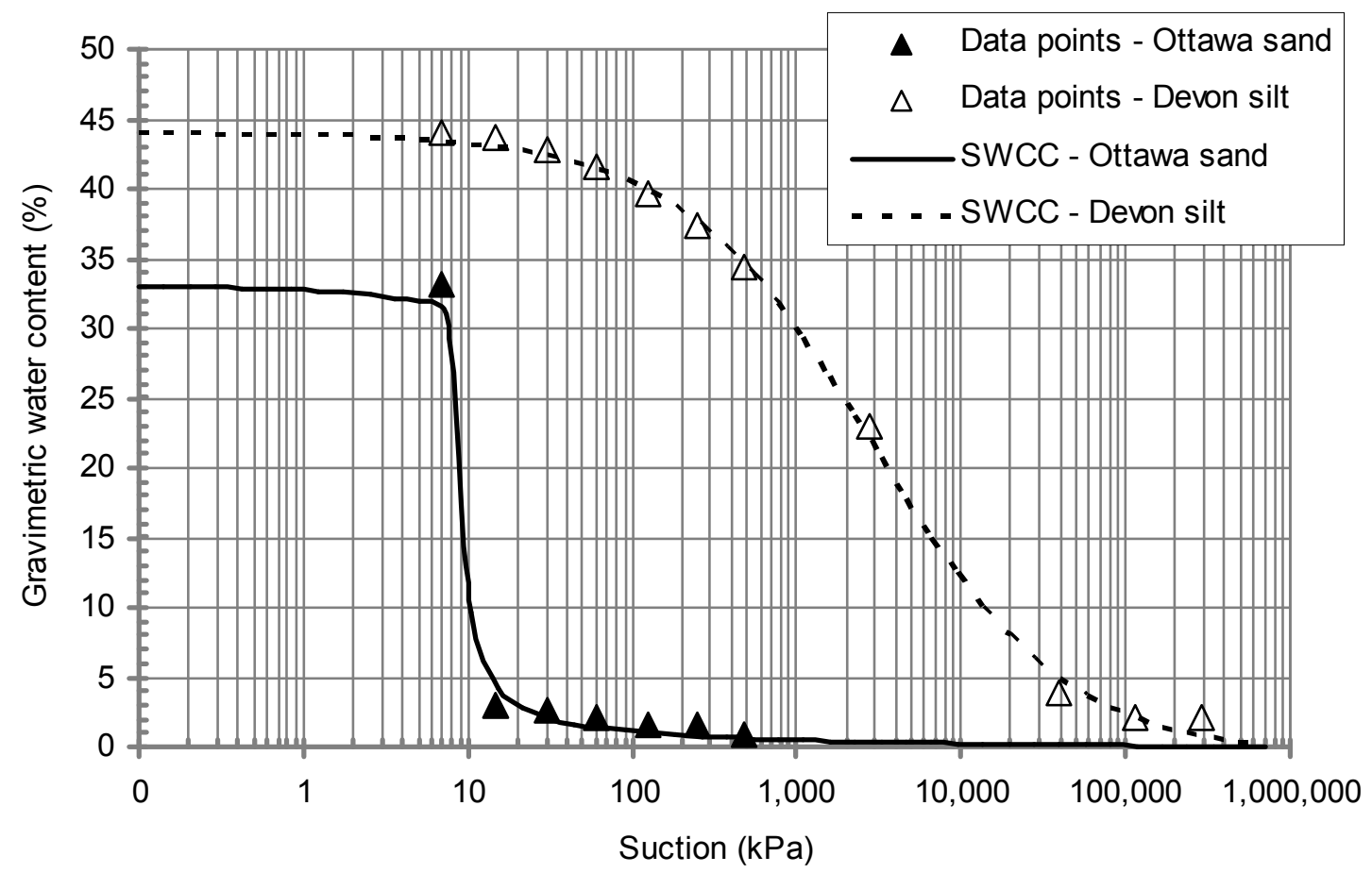

Figure 2: Drying soil-water characteristic curves for Ottawa sand and Devon silt using the Fredlund and Xing (1994) fitting curves. 


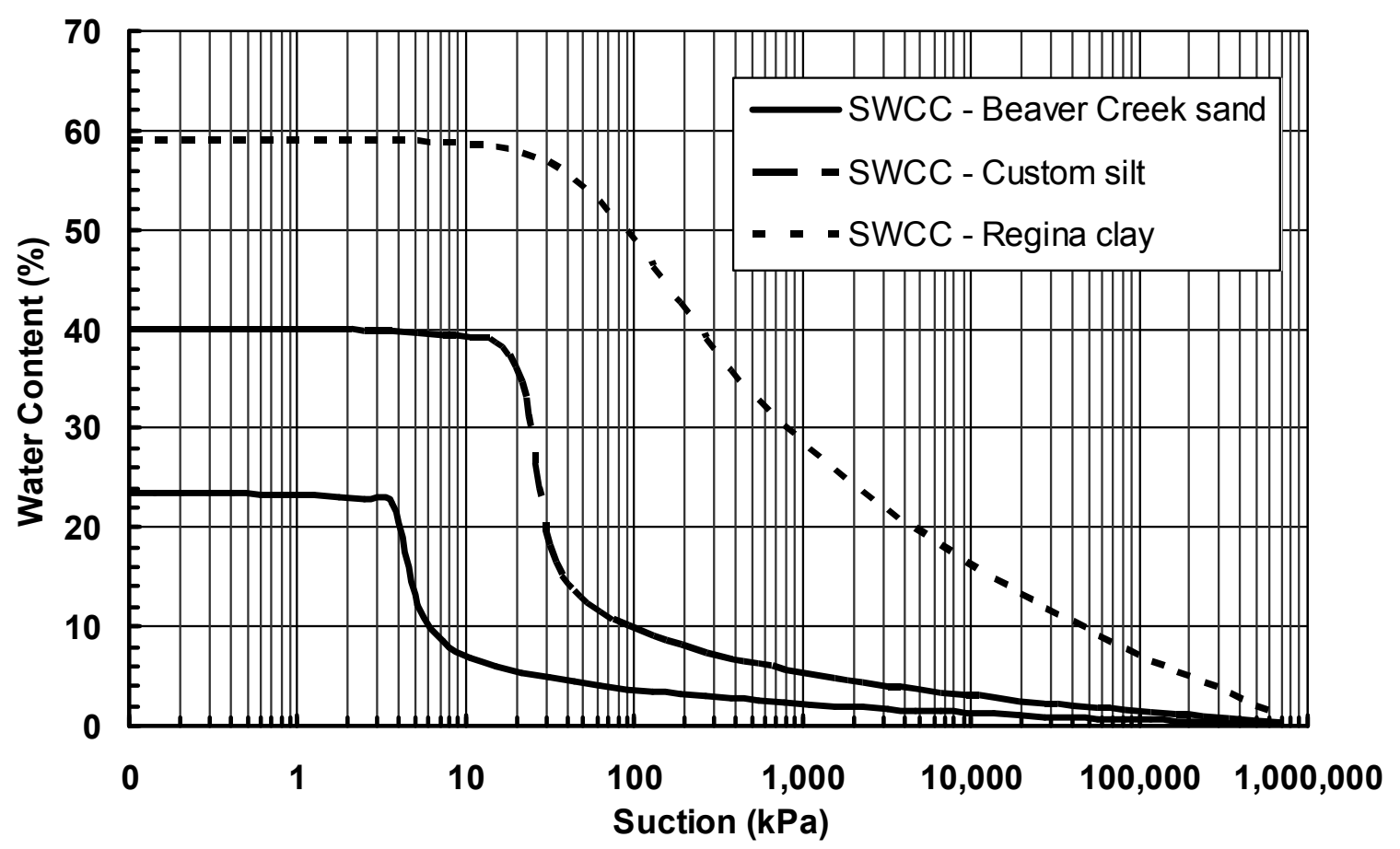

Figure 3: Fredlund and Xing (1994) Soil-water characteristic curves for the sand, silt and clay (from Wilson 1990).

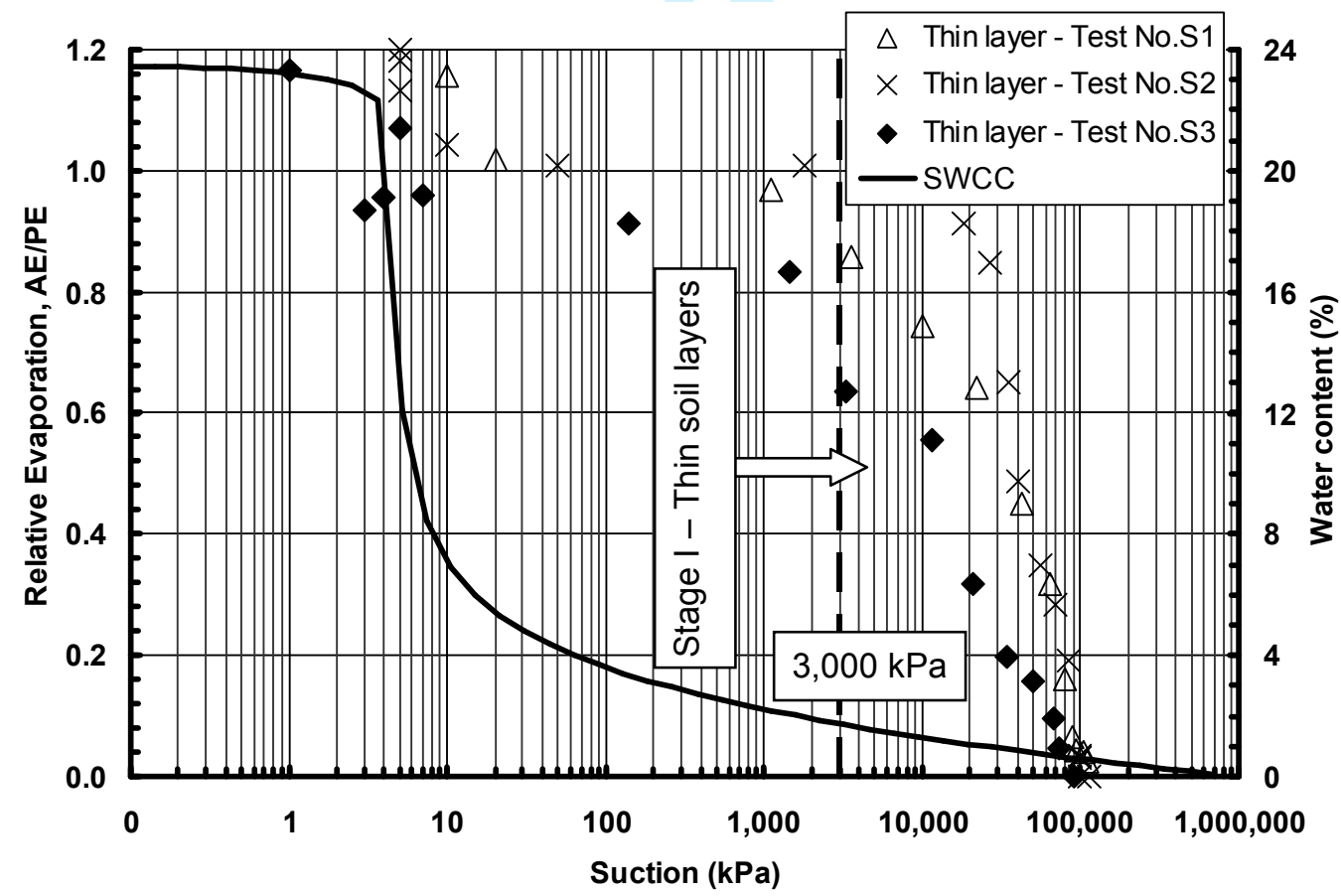

Figure 4: Extent of Stage I of the evaporative process for thin soil layers of the Beaver Creek sand (data from Wilson 1990). 


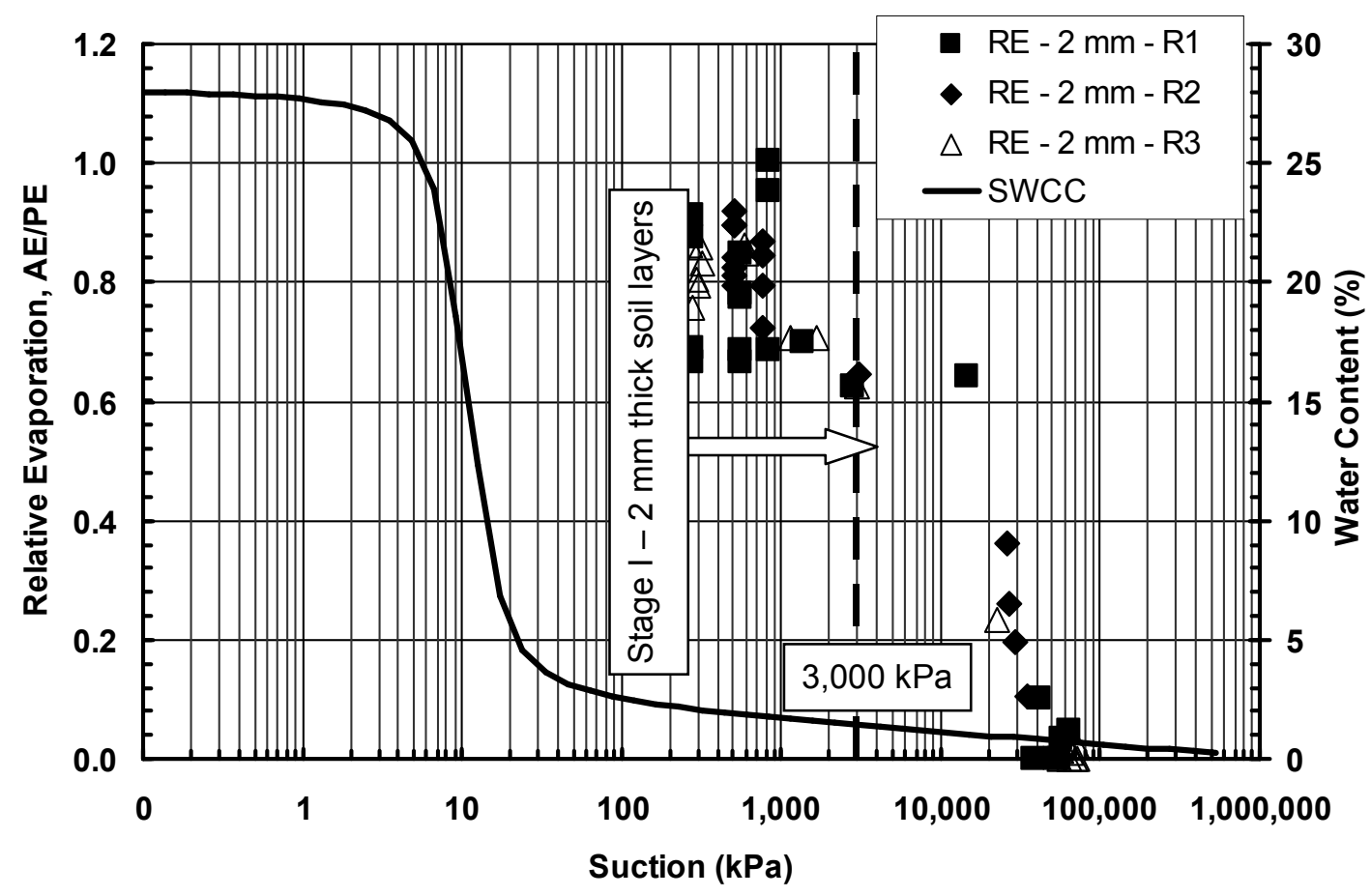

Figure 5: Illustration of extent of Stage I of the evaporative process for thin soil layers of the non-saline silt (data from Dunmola 2012).

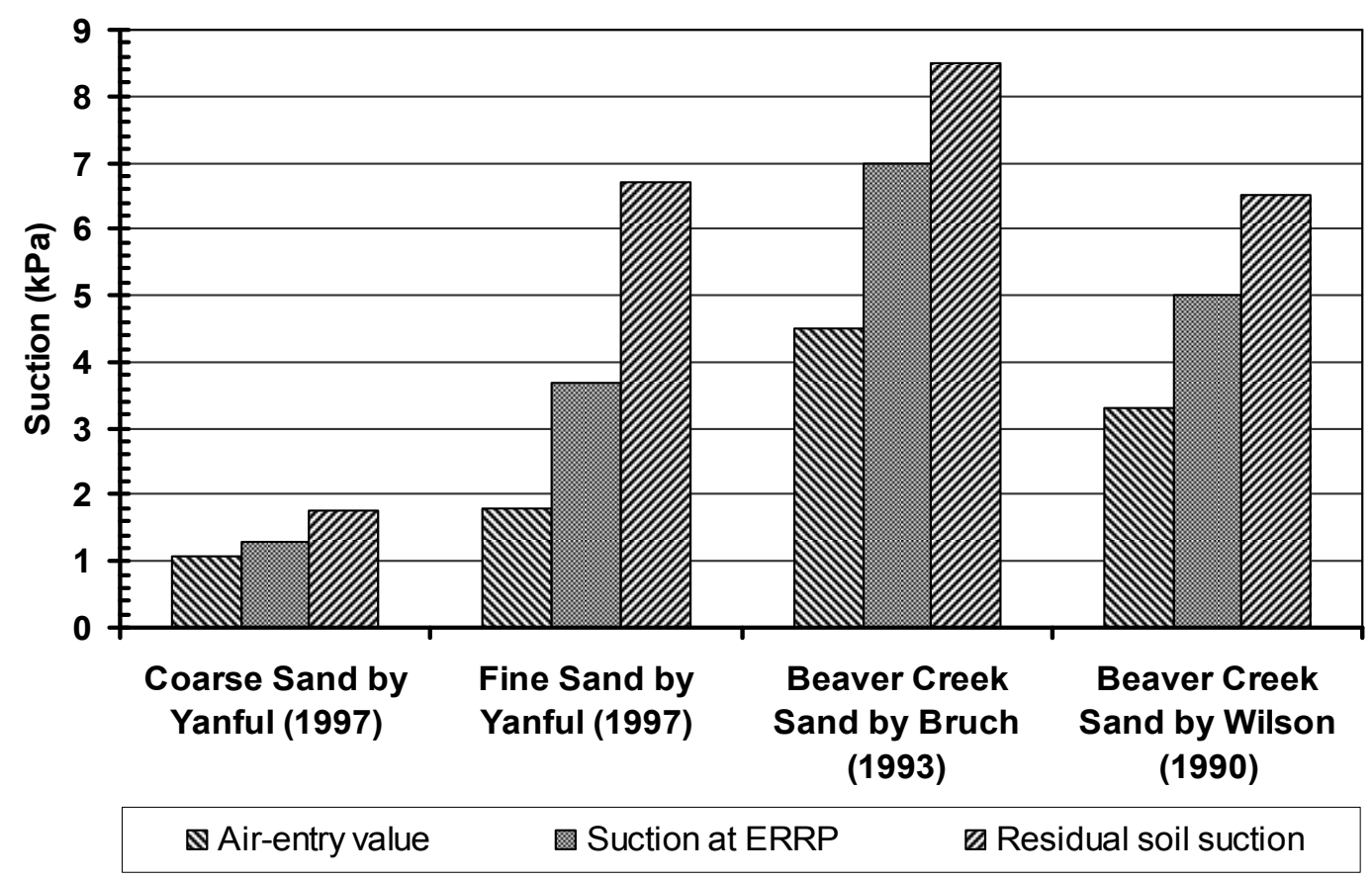

Figure 6: Comparison of the air-entry value, residual soil suction and suction at the ERRP (data collected from the drying experiments by Wilson 1990; Bruch 1993; Yanful and Choo 1997). 


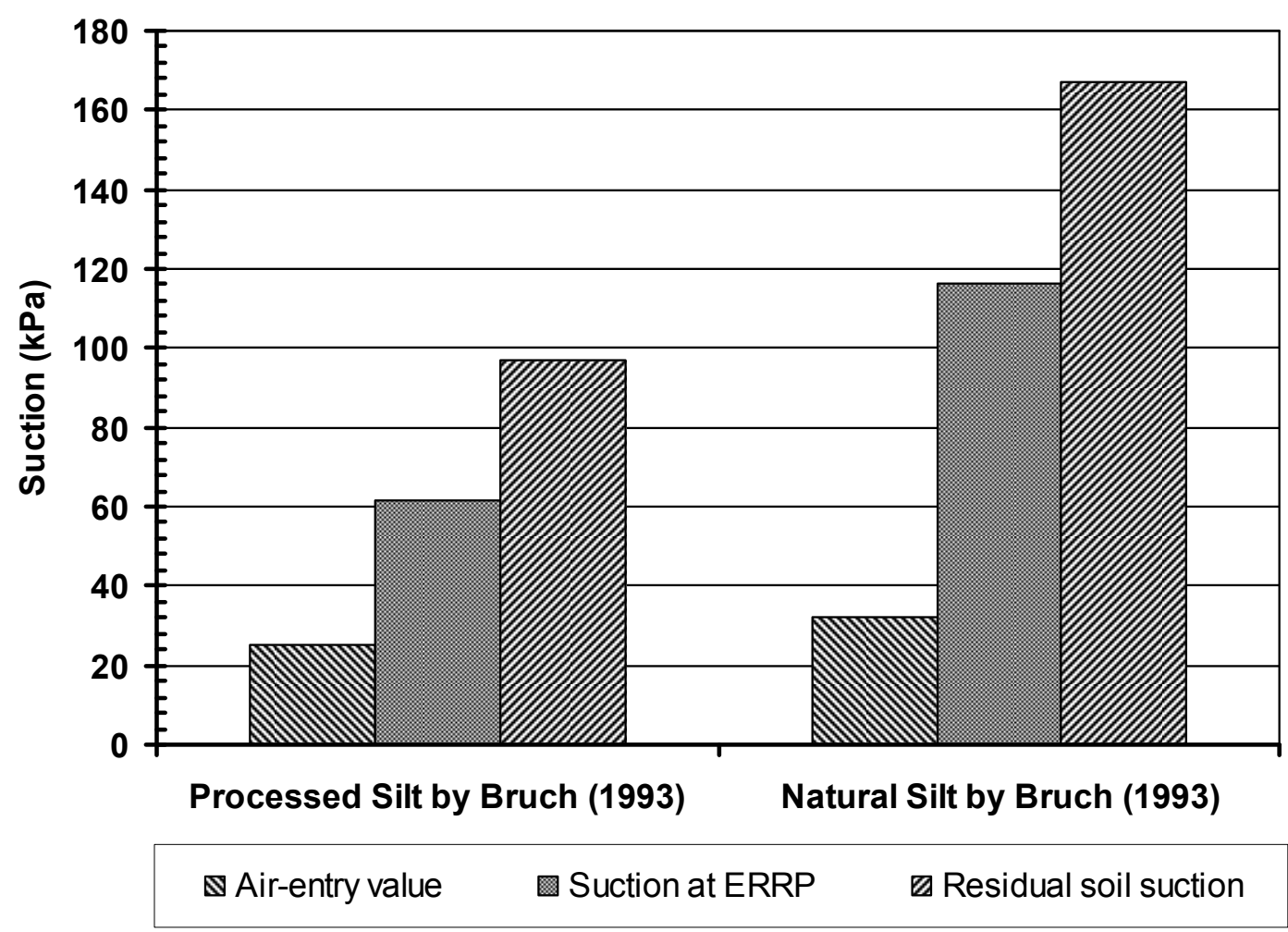

Figure 7: Comparison of the air-entry value, residual soil suction and suction at the ERRP (data collected from the drying experiments by Bruch 1993).

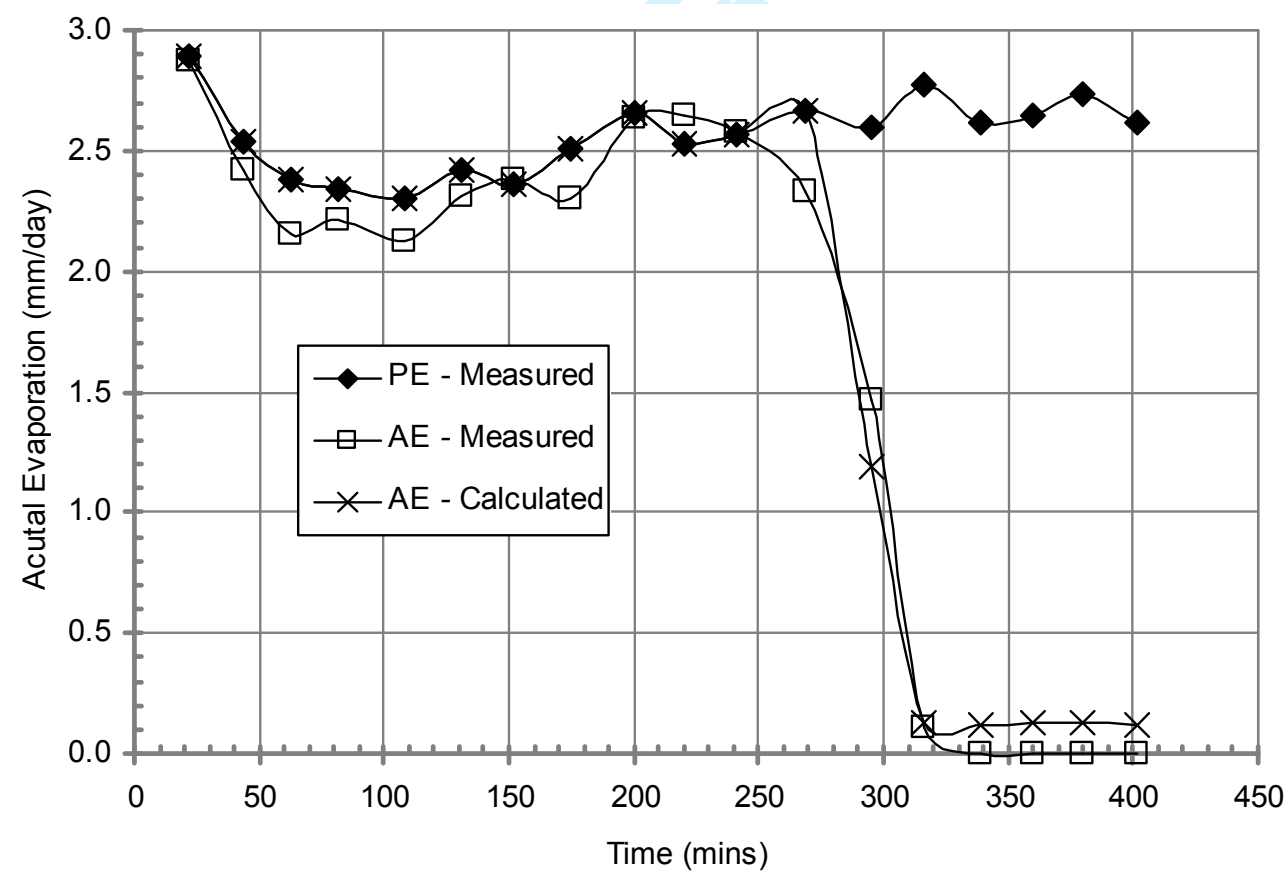

Figure 8: Calculated, actual and potential evaporation rates for thin non-saline Ottawa sand. 


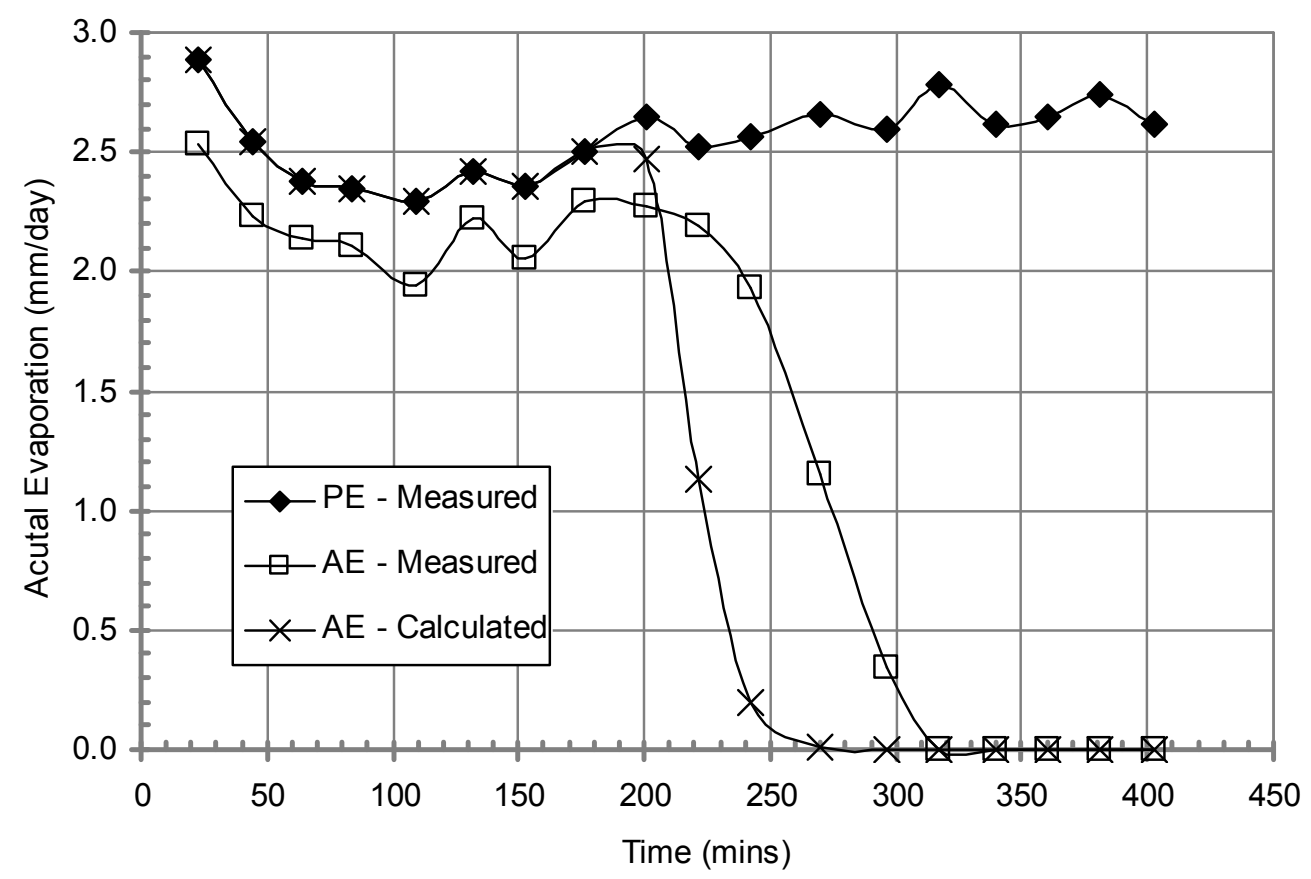

Figure 9: Calculated, actual and potential evaporation rates for thin Devon silt with the water content at a total suction of $3,000 \mathrm{kPa}$ used as a reference point for vapour pressure at the soil surface.

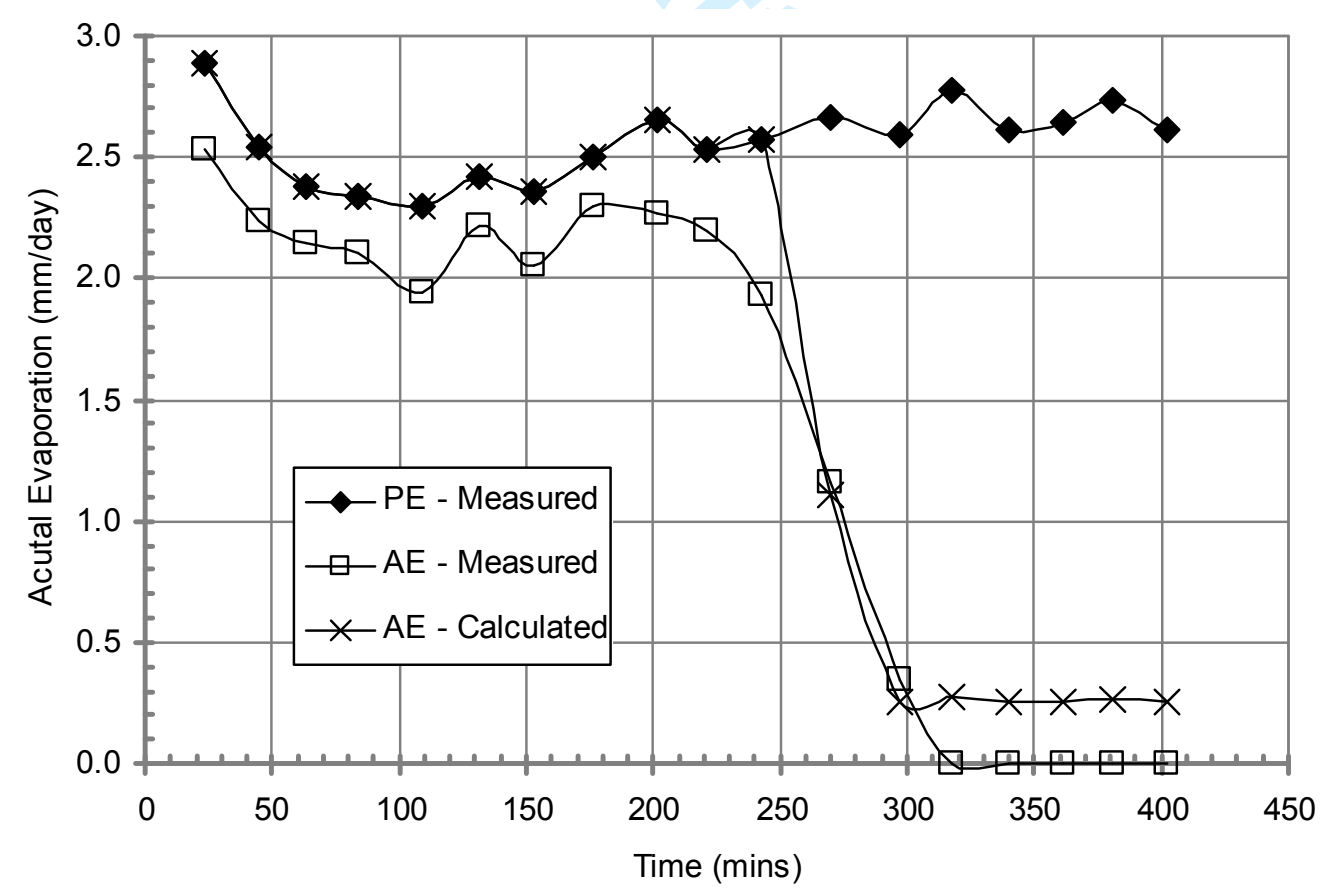

Figure 10: Calculated, actual and potential evaporation rates for thin layer of Devon silt using the water content at the ERRP observed during the drying test. 


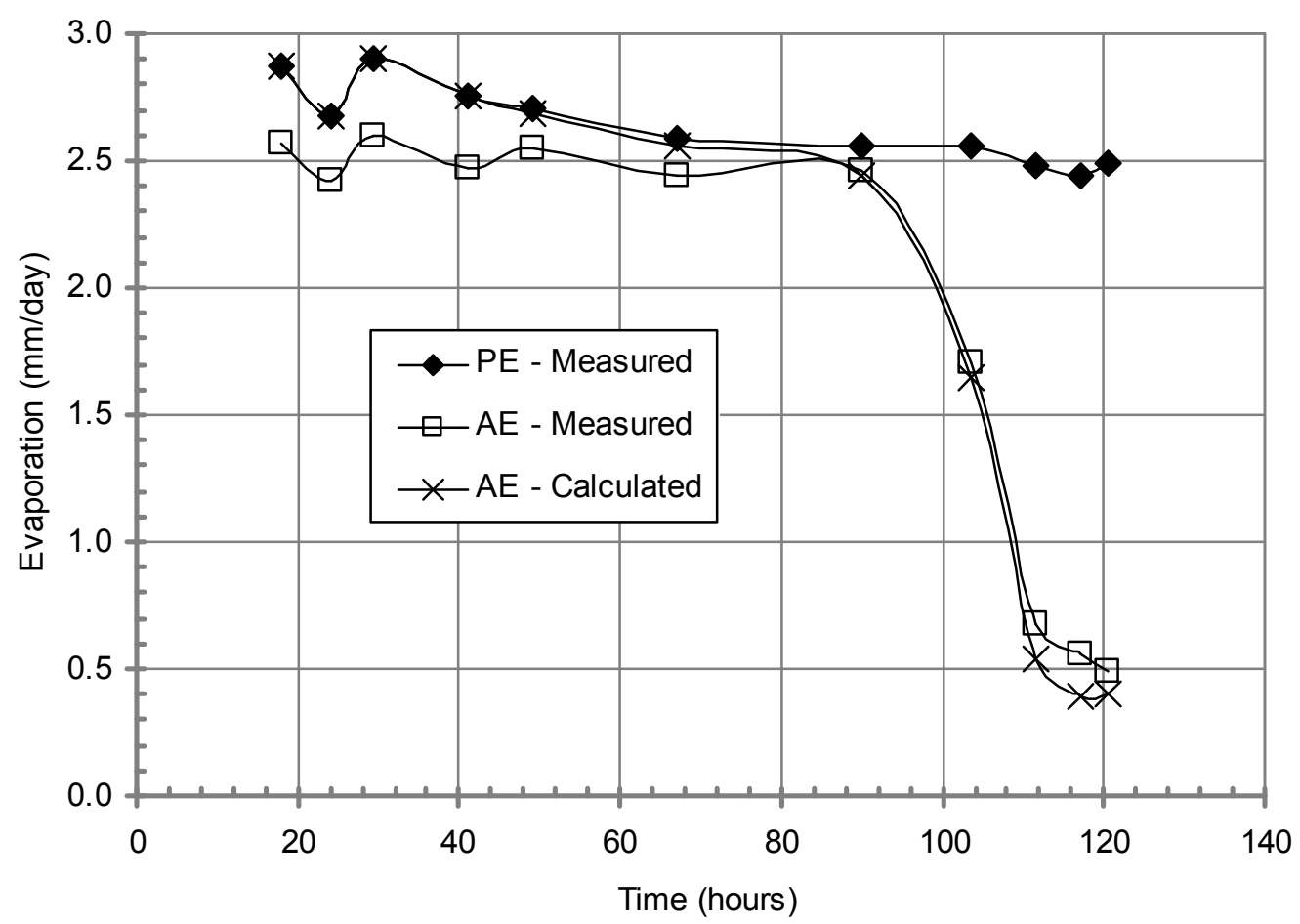

Figure 11: Calculated, actual and potential evaporation rates for thick Ottawa sand (i.e., $3 \mathrm{~cm}$ thick).

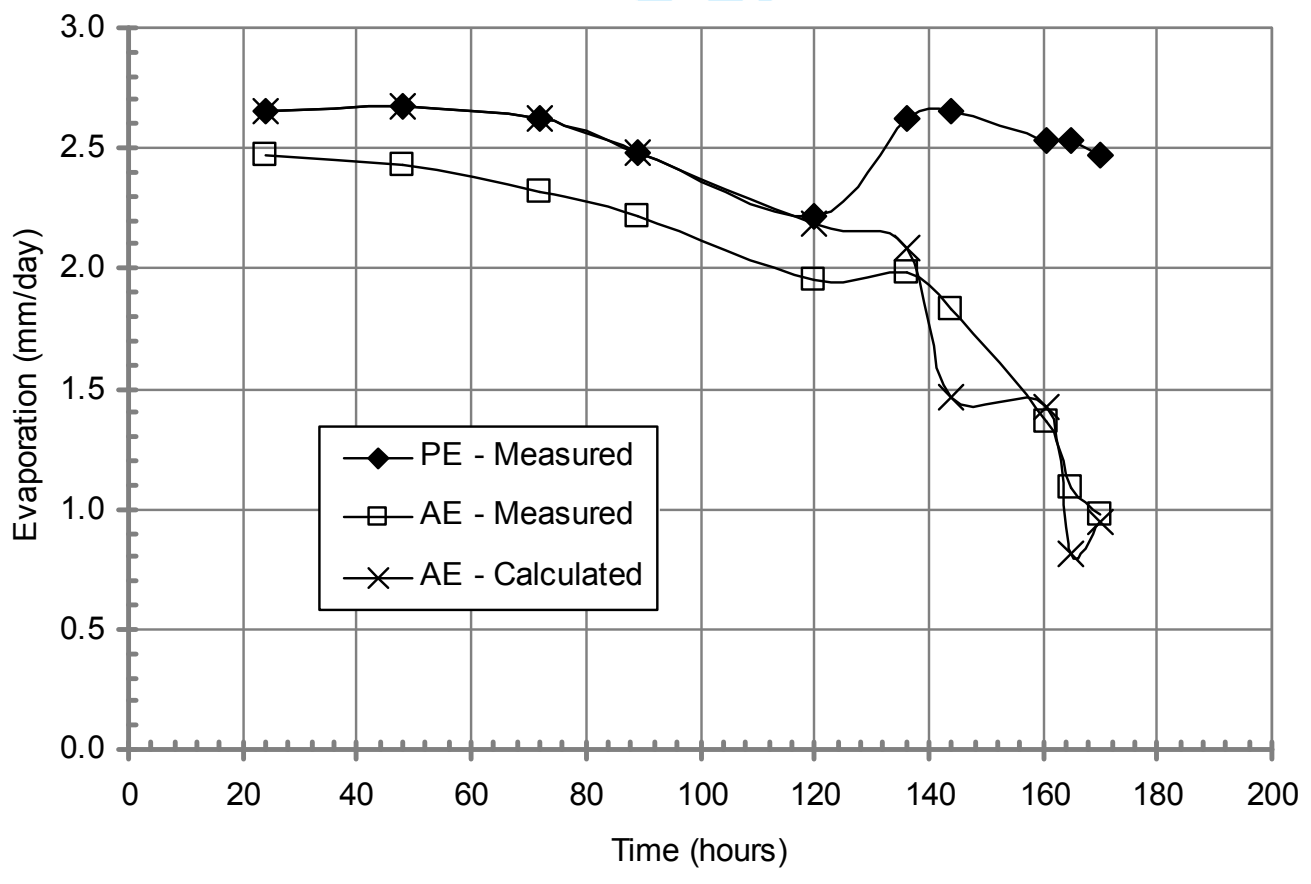

Figure 12: Calculated, actual and potential evaporation rates for thick Devon silt (i.e., $3 \mathrm{~cm}$ thick). 


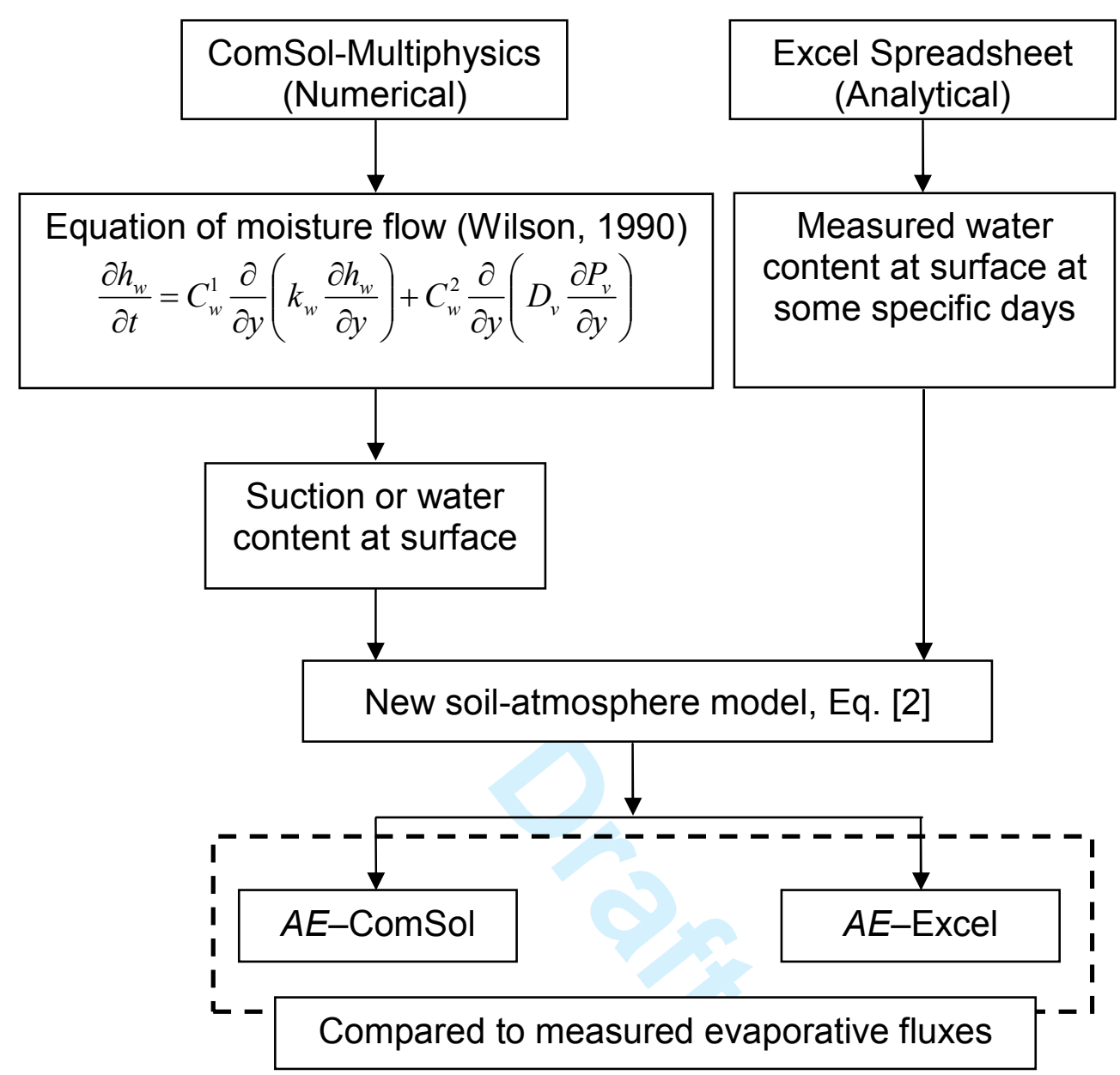

Figure 13: Illustration of two procedures used in the verification of the new soilatmosphere model. 


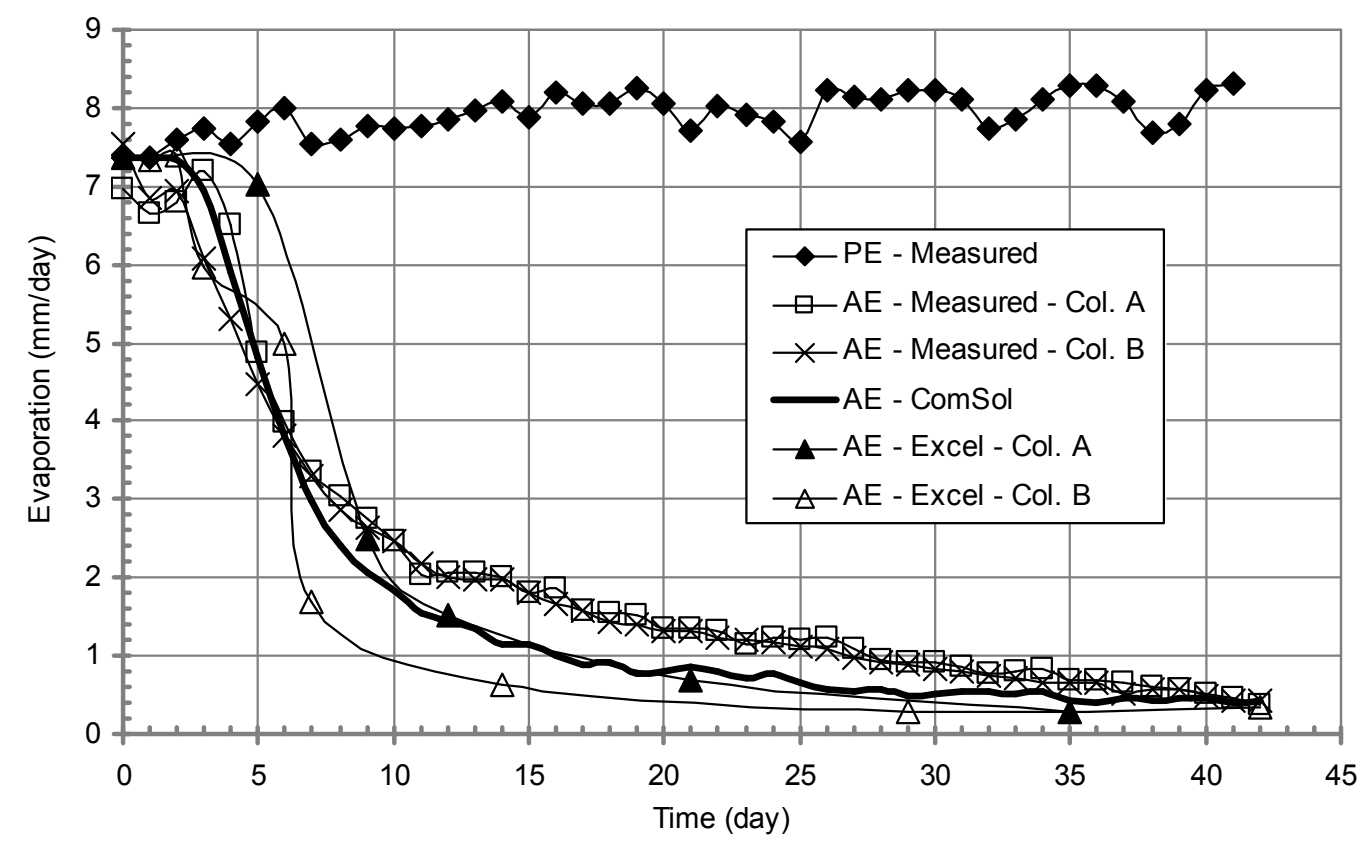

Figure 14: Calculated and measured evaporation rates for soil columns $A$ and $B$ of Beaver Creek sand (data from Wilson 1990).

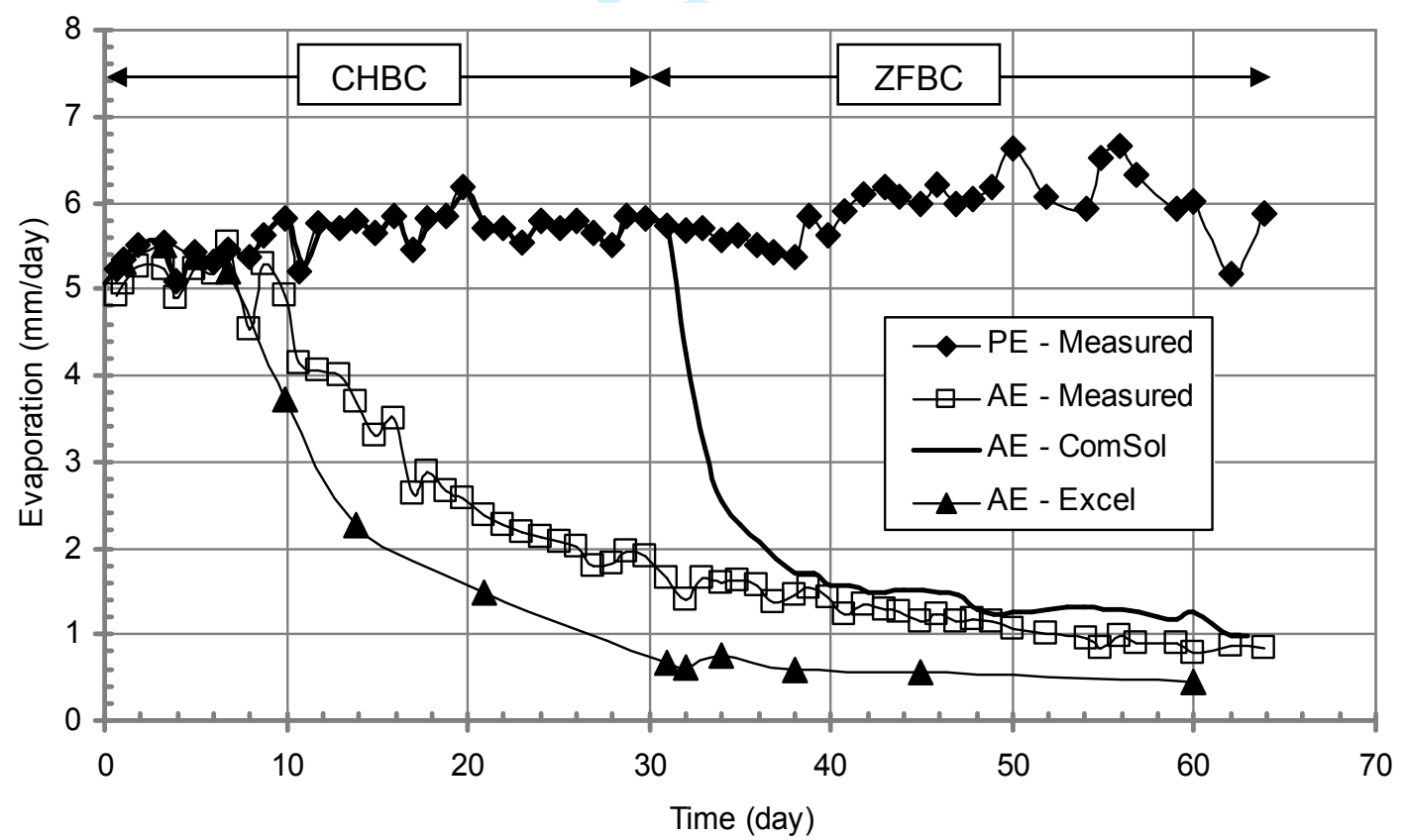

Figure 15: Calculated and measured evaporation rates for the soil column of Beaver Creek sand (data from Bruch 1993). 


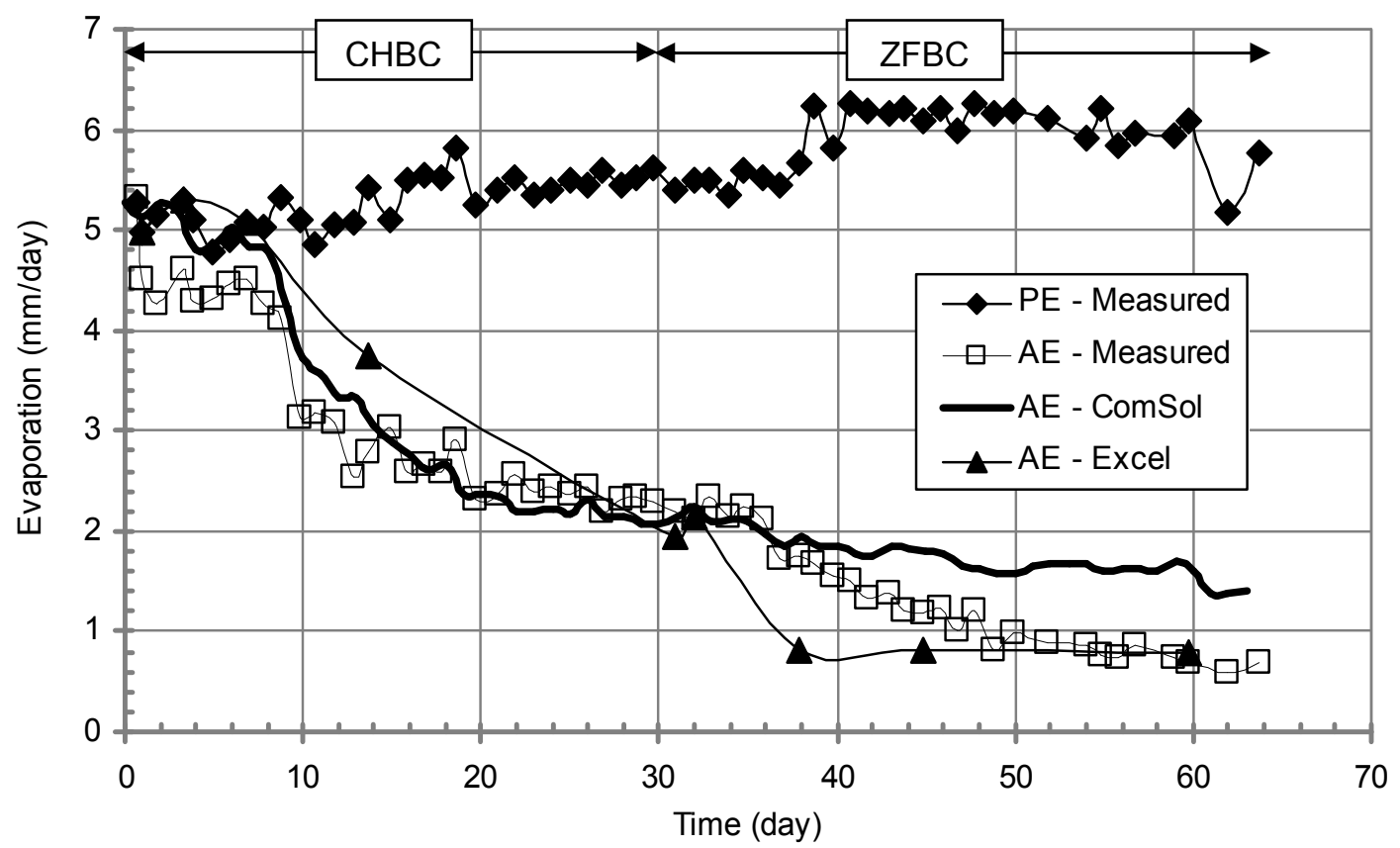

Figure 16: Calculated and measured evaporation rates for the soil column of Processed silt (data from Bruch 1993).

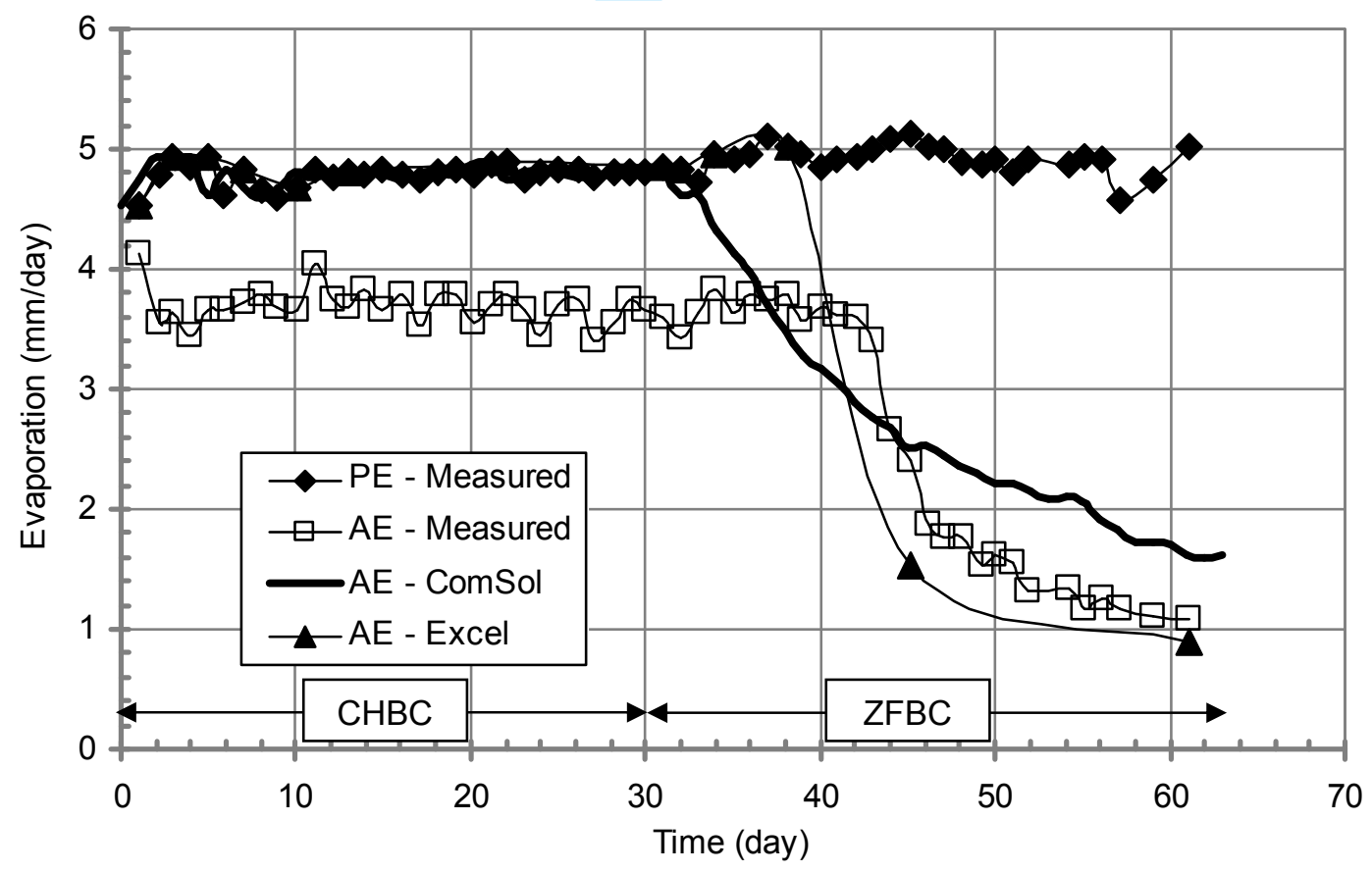

Figure 17: Calculated and measured evaporation rates for the soil column of Natural silt (data from Bruch 1993). 


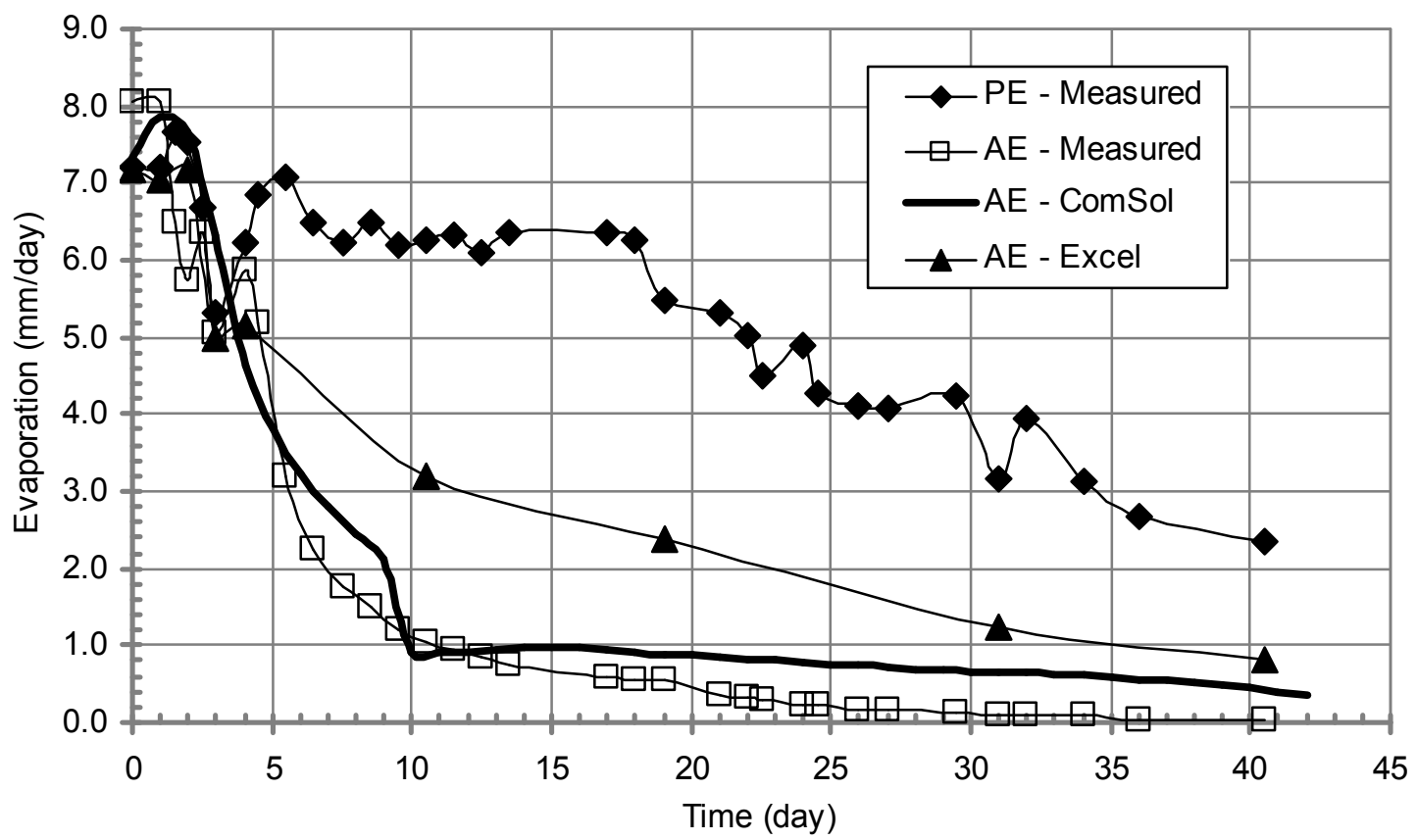

Figure 18: Calculated and measured evaporation rates for the soil column of the coarse sand (data from Yanful and Choo 1997).

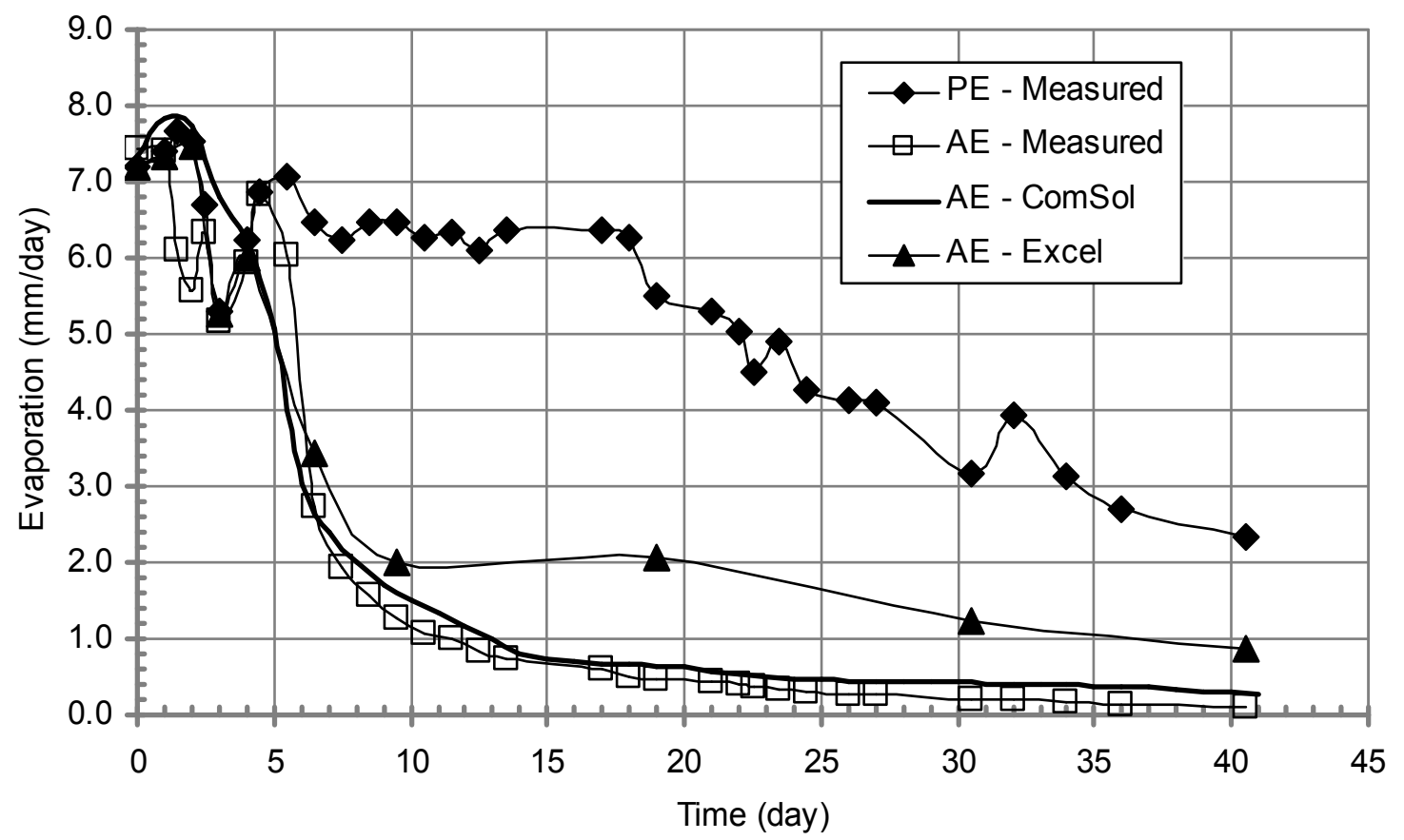

Figure 19: Calculated and measured evaporation rates for the soil column of the fine sand (data from Yanful and Choo 1997). 


\section{List of Tables}

Table 1: Equations for the Soil "Surface Resistance"

Table 2: Approximate Equilibrium Relative Humidity for Selected Saturated Salt Solutions at 20 degrees Celsius

Table 3: $\quad$ Summary of Soil Types and Properties Used for Verification Using ComSolMultiphysics 
Table 1: Equations for the Estimation of Soil "Surface Resistance" for Soil Columns

\begin{tabular}{|c|c|c|}
\hline References & Equation & Fitting Parameters \\
\hline Fen Shu (1982) & $r_{s}=3.5\left(\frac{\theta_{\text {sat }}}{\theta}\right)^{2.3}+33.5$ & $\begin{array}{l}\theta=\text { volumetric water content in } \\
\text { the } 0-5 \mathrm{~mm} \text { soil layer; } \\
\theta_{\text {sat }}=\text { saturated water content of } \\
\text { the soil. }\end{array}$ \\
\hline $\begin{array}{l}\text { Camillo and } \\
\text { Gurney (1986) }\end{array}$ & $r_{s}=-885+4,140\left(\theta_{\text {sat }}-\theta_{\text {top }}\right)$ & $\begin{array}{l}\theta_{\text {sat }}=\text { saturated volumetric soil } \\
\text { water content, } \\
\theta_{\text {top }}=\text { volumetric water content } \\
\text { of the first } 0-0.5 \mathrm{~cm} \text { top surface } \\
\text { layer: }\end{array}$ \\
\hline $\begin{array}{l}\text { van de Griend } \\
\text { and Owe (1994) }\end{array}$ & $r_{s}=10 \times e^{0.3563(15-\theta)}$ & $\begin{array}{l}\theta=\text { soil volumetric water content } \\
\text { (percentage) in the top } 1 \mathrm{~cm}\end{array}$ \\
\hline
\end{tabular}

Table 2: Approximate Equilibrium Relative Humidity and Total Suction for Selected Saturated Salt Solutions at 20 degrees Celsius

\begin{tabular}{|c|c|c|}
\hline Salt Solution & Average Relative Humidity (\%) & Total Suction (kPa) \\
\hline Lithium chloride & 12 & 286,350 \\
\hline Sodium chloride & 75 & 37,960 \\
\hline Potassium chloride & 85 & 21,790 \\
\hline Potassium sulfate & 98 & 3,755 \\
\hline
\end{tabular}


Table 3: $\quad$ Summary of Soil Types and Properties Used for Verification Using ComSolMultiphysics

\begin{tabular}{|l|c|c|c|c|c|c|}
\hline Soil Type & $\begin{array}{c}\text { Method } \\
\text { Estimating } \\
\text { SWCC }\end{array}$ & $\begin{array}{c}\text { Saturated } \\
\text { Hydraulic } \\
\text { Conductivity } \\
\mathbf{( m / s )}\end{array}$ & $\begin{array}{c}\text { Method } \\
\text { Estimating } \\
\text { Unsaturated } \\
\text { Hydraulic } \\
\text { Conductivity }\end{array}$ & $\begin{array}{c}\text { Suction } \\
\text { at ERRP } \\
\text { (kPa) }\end{array}$ & $\begin{array}{c}\text { Volumetric } \\
\text { Water } \\
\text { Content at } \\
\text { ERRP (\%) }\end{array}$ & Sources \\
\hline $\begin{array}{l}\text { Beaver } \\
\text { Creek sand }\end{array}$ & $\begin{array}{c}\text { Fredlund and } \\
\text { Xing (1994) }\end{array}$ & $3.0 \times 10^{-5}$ & $\begin{array}{c}\text { Fredlund and } \\
\text { Xing (1994) }\end{array}$ & 5.0 & 18 & $\begin{array}{c}\text { Wilson } \\
(1990)\end{array}$ \\
\hline $\begin{array}{l}\text { Beaver } \\
\text { Creek sand }\end{array}$ & $\begin{array}{c}\text { Fredlund and } \\
\text { Xing (1994) }\end{array}$ & $3.9 \times 10^{-6}$ & $\begin{array}{c}\text { Brooks and } \\
\text { Corey (1964) }\end{array}$ & 7.0 & 18 & $\begin{array}{c}\text { Bruch } \\
(1993)\end{array}$ \\
\hline $\begin{array}{l}\text { Processed } \\
\text { silt }\end{array}$ & $\begin{array}{c}\text { Fredlund and } \\
\text { Xing (1994) }\end{array}$ & $8.39 \times 10^{-9}$ & $\begin{array}{c}\text { Brooks and } \\
\text { Corey (1964) }\end{array}$ & 62 & 15 & $\begin{array}{c}\text { Bruch } \\
(1993)\end{array}$ \\
\hline Natural silt & $\begin{array}{c}\text { Fredlund and } \\
\text { Xing (1994) }\end{array}$ & $2.07 \times 10^{-8}$ & $\begin{array}{c}\text { Brooks and } \\
\text { Corey (1964) }\end{array}$ & 116 & 14 & $\begin{array}{c}\text { Bruch } \\
(1993)\end{array}$ \\
\hline Fine sand & $\begin{array}{c}\text { Fredlund and } \\
\text { Xing (1994) }\end{array}$ & $1.0 \times 10^{-5}$ & $\begin{array}{c}\text { Brooks and } \\
\text { Corey (1964) }\end{array}$ & 1.5 & 15 & $\begin{array}{c}\text { Yanful and } \\
\text { Choo } \\
(1997)\end{array}$ \\
\hline $\begin{array}{l}\text { Coarse } \\
\text { sand }\end{array}$ & $\begin{array}{c}\text { Fredlund and } \\
\text { Xing (1994) }\end{array}$ & $2.0 \times 10^{-4}$ & $\begin{array}{c}\text { Brooks and } \\
\text { Corey (1964) }\end{array}$ & 3.7 & 15 & $\begin{array}{c}\text { Yanful and } \\
\text { Choo } \\
(1997)\end{array}$ \\
\hline
\end{tabular}

